This document was prepared in conjunction with work accomplished under Contract No.

DE-AC09-76SR00001 with the U.S. Department of Energy.

\title{
DISCLAIMER
}

This report was prepared as an account of work sponsored by an agency of the United States Government. Neither the United States Government nor any agency thereof, nor any of their employees, makes any warranty, express or implied, or assumes any legal liability or responsibility for the accuracy, completeness, or usefulness of any information, apparatus, product or process disclosed, or represents that its use would not infringe privately owned rights. Reference herein to any specific commercial product, process or service by trade name, trademark, manufacturer, or otherwise does not necessarily constitute or imply its endorsement, recommendation, or favoring by the United States Government or any agency

thereof. The views and opinions of authors expressed herein do not necessarily state or reflect those of the United States Government or any agency thereof.

This report has been reproduced directly from the best available copy.

Available for sale to the public, in paper, from: U.S. Department of Commerce, National Technical Information Service, 5285 Port Royal Road, Springfield, VA 22161, phone: (800)

553-6847, fax: (703) 605-6900, email: orders@ntis.fedworld.gov online ordering: http://www.ntis.gov/ordering.htm

Available electronically at http://www.doe.gov/bridge

Available for a processing fee to U.S. Department of Energy and its contractors, in paper, from: U.S. Department of Energy, Office of Scientific and Technical Information, P.O. Box 62, Oak Ridge, TN 37831-0062, phone: (865 ) 576-8401, fax: (865) 576-5728, email: reports@ adonis.osti.gov 
TECHN ICAL DIVISION

SAVANNAH RIVER LABORATORY
DPST $-81-828$

CC: J. R. Hilley, SRL

J. A. Porter

J. G. Smith

E. I. Wilhite

M. H. Tennant

H. B. Peacock, Jr.

J. D. Stewart

A. Gibbs

J. R. Cadieux

R. S. Swingle, SRP

J. H. Owen

P. T. Deason

R. S. Thomason

R. I. Frontroth

TIS File (2)

ACC.NO. 140197

TO:

M. I. HYDER/D . A . WARD

FROM :

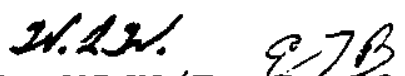

W. G. WINN/E. T. BOOTH

TIS FILE

RECORD COPY

\section{APPRAISAL OF ACTIVE WELL COINCIDENCE COUNTER FOR URANIUM ACCOUNTABILITY}

\section{Introduction}

The Active Well Coincidence Counter (AWCC) is a relatively inexpensive $(\$ 50 \mathrm{~K})$ instrument for monitoring fissile materials.1-7 currently, SRL/SRP relies heavily on the more expensive $(\$ 500 \mathrm{~K})$ Cf shuffler in 300-Area for such interrogation.8-9 Because the AWCC provides a quick non-destructive assay, it also has advantages over other methods in use, such as mass spectroscopy. Thus, the FAB lab has coordinated recent feasibility studies on the AWCC. These follow earlier studies on billet samples at 300-Area, ${ }^{5}, 11$, and include: (1) $\mathrm{U}_{3} \mathrm{O}_{8}$ 
M... L. HYDER/D. A. - WARD - H - DST-81-828

November 10,1981

powders received at the FAB labl2, (2) two low-mass uranium standards provided by New Brunswick Laboratories $13-14$, and (3) scrap can samples from 300-Area15-16. These samples ranged from 0 to $7 \mathrm{Kg}$ in $235 \mathrm{U}$. It was desirable to see whether the AWCC could make assays to Io accuracy.

The AWCC, developed at LASL, uses two AmLi sources to produce fissions in a sample with uranium. The resulting fission neutrons are detected in coincidence at a rate governed by the amount of $235 \mathrm{U}$ in the sample. The count rates provide 2350 assays with statistical accuracy to <18, in less than an hour of counting, but systematic errors require examination for complete appraisal.

This study emphasized the AWCC capabilities for the $\mathrm{U}_{3} \mathrm{O}_{8}$ powder samples, which ranged up to $12 \mathrm{Kg}$ in mass and 938 in $235 \mathrm{U}$ enrichment. In particular, it was desired to (1) identify and correlate the sample parameters which were sensitive to count rate, and (2) appraise the reliability of measurements with the AWCC. For the other types of samples, which had less $235 \mathrm{U}$, the projected measurement errors were much larger than 18 , and detailed parameter tests were not performed.

\section{Summary}

These studies demonstrated an AWCC measurement capability accurate to $\sim 28$ at 958 confidence level, for $\mathrm{Kg}$ amounts of $235 \mathrm{U}$ in $\mathrm{U}_{3} \mathrm{O}_{8}$ powder. This performance corresponded to count times of $2000 \mathrm{sec}$. A careful study of the measurement errors projected that the accuracy may be improved to It with suitable controls. The demonstrated accuracy was considerably worse for samples having $<1 \mathrm{Kg} 235 \mathrm{U}$. Also, the scrap sample measurements may have been affected by sample inhomogenieties.

A good empirical fit to the $\mathrm{U}_{3} \mathrm{O}_{8}$ powder data was obtained and could be interpreted physically. This indicates that Monte Carlo5, 17 calculations for the AWCC could be used to reduce the effort required for producing AWCC calibration data.

\section{Experimental Aspects}

A. AWCC Description

The AWCC measures the amount of $235_{\mathrm{U}}$ in a sample by monitoring the fission rate induced by two $\operatorname{AmL} i(\alpha, n)$ neutron sources. Each source has $0.71 \mathrm{gm} 241_{\mathrm{Am}}$ and produces
$1.7 \times 10^{5}$
$\mathrm{n} / \mathrm{sec} .18$
A block diagram of the instrumentation is 
M. - L. HYDER/D. A. =WARD

DPST-8I-828

November 10,1981 shown in Figure 1. Detailed information on the AWCC is avail-
able.1,3

The sample is placed in a central cavity of a $19^{\prime \prime}$ diameter by $24 "$ high polyethylene barrel. The two AmLi sources are situated just above and below the sample so that the sample is irradiated reasonably uniformly with fast neutrons. Cadmium shielding about the sources, as shown in Figures 2 and 3 , reduces non-uniform sample irradiation by thermal neutrons. In addition, an annular nickel reflector about the center of the cavity enhances the more penetrating irradiation of fast neutrons in the sample. The n-irradiated sample produces fissions which release several neutrons per a single fission. These fission neutrons are correlated per a given fission; thus, detection of two or more neutrons in coincidence yields a measure of the fission rate or $235 \mathrm{U}$ content.

The neutrons are detected by 42 3 $\mathrm{He}$ detectors which are located in an outer annulus of the polyethylene barrel, as shown in Figure 1. Each detector has 1 in. diameter and 20 in. length. Cadmium shielding about the inner and outer surfaces of the detector annulus reduces the neutron background from the AmL $i$ sources and the room, and thus helps reduce the random coincidence background from these effects. The polyethylene within the detector annulus helps thermalize the fission neutrons so that the 3 He-detector efficiency is enhanced.

The detection electronics is also shown in Figure 1. A single high voltage $(1500 \mathrm{~V})$ supply is connected to all 42 ${ }^{3}$ He detectors. The detector outputs are ganged in 6 groups of 7 detectors each. Each detector group has its own preamp, amplifier, and level discriminators, so that the effects of pileup are reduced. The shorter duration discriminator output pulses of each group are passed through an OR gate and then into a shift-register coincidence counter (SRCC) 3,19 The SRCC electronically stores, in a special counter, each neutron pulse for a time interval ( $64 \mu$ sec)* for which most real (fission) coincidences should occur. In addition, each neutron pulse strobes this counter just before its storage in counter and then $\sim 1000 \mu \mathrm{sec}$ after its departure from counter. The immediate strobe obtains the real (R) plus random (A) coincidence in the counter, while the delayed strobe obtains only the random coincidences ( $A$ ) in the counter. The accumulated $R+A$ and $A$ for $a$ given count time $t$, as well as the total neutron count $T$, are tallied by a microprocessor. After counting, the data in the microprocessor are passed to a HP-97 programmable calculator.

* The maximum total count rate is usually $<1 / 64 \mu$ sec or $15,000 / \mathrm{sec}$ 
M. I $\div$ HYDER $/ D ; A \cdot-$ WARD

A code then calculates $T, R+A, A, t, R$ and asociated counting errors. $f$

\section{B. Samples}

$\mathrm{U}_{3} \mathrm{O}_{8}$ Powder Samples $\mathrm{Th}_{3} \mathrm{U}_{3} \mathrm{O}_{8}$ powder samples ranged from $2 \mathrm{~kg}$ to $12 \mathrm{~kg}$, with $235 \mathrm{U}$ enrichments from 0.17 to 938 , as summarized in Appendix Tables A.1-A.4I2. Various of these samples were contained in three different types of steel cans. Dimensions for these cans and the corresponding AWCC counting geometries are given in Figures 2 and 3.

Scoping studies used the AwCC geometry of Figure 2 . Either oxide storage cans (OSC) or \#10 cans contained the sample. Each OSC container had a polyurethane top and was enclosed in a polyethylene bag. Each \#10 can was sealed with a metal lid and thus required no outer polyethylene bag; however, the $\mathrm{U}_{3} \mathrm{O}_{8}$ was contained within a polyethylene bag inside each can. Data obtained for these samples are detailed in Appendix Tables A.1 and A.2.

The detailed studies used the AWCC geometry of Figure 3. Only \#10 cans were used in this case. Each \#10 can had a polyurethane top and was enclosed in a polyethylene bag. No polyethylene bag was used inside the can. Five \#10 cans with $12.00 \mathrm{Kg}$ of $\mathrm{U}_{3} \mathrm{O}_{8}$ of different enrichment were prepared and counted in the AWCC. Then $2.00 \mathrm{~kg}$ from each of these cans were placed in five additional \#10 cans, whereby cans of $10.00 \mathrm{Kg}$ and $2.00 \mathrm{Kg}$ were counted. Similarly, these cans were remeasured for 8.00 and $4.00 \mathrm{Kg}$ samples and finally, for $6.00 \mathrm{Kg}$ and $6.00 \mathrm{Kg}$. This procedure resulted in the data summarized from detailed data in Appendix Tables $A .3$ and A.4. in Table I. The $6.00 \mathrm{Kg}$ samples were counted repeatedly, on various days, to yield detailed information on measurement reproducibility. A $12.00 \mathrm{Kg}$ depleted sample was also counted.

New Brunswick Samples The two New Brunswick Laboratory samples $13-14$ each had a net weight of $950 \mathrm{gm}$, contained in a 3 3/8"-diameter $x$ 8" tall polypropylene can. One sample had no $235 \mathrm{U}$ and the other had $125.35 \mathrm{gm}$ of $235_{\mathrm{U}}$ of a total of $134.78 \mathrm{gm} \mathrm{U}$, as indicated in Appendix Table A.5. Each sample was counted, using the AWCC geometry of Figure 3 .

$\bar{f}$ An RS-232 output is also available on the microprocessor. 
M. L. HYDER/D - A- WARD

$-5-$

DPST-81-828

November 10,1981

300-Area Scrap Samples The scrap uranium samples $15-16$ were 300-Area "floor sweepings." In all, there were six samples ranging from 140 to $420 \mathrm{gm}$ of $235 \mathrm{U}$, as shown in Appendix Table A.6. Each of these samples was contained in a "short" \#10 can* and counted in the AWCC geometry of Figure 3.

\section{Measurement Techniques}

Before introducing any sample into the AWCC, the instrument settings described in section IIIA were confirmed. Upon daily power up, the AWCC measured (1) the background to check that it was zero within statistics, and (2) a $\mathrm{U}_{3} \mathrm{O}_{8}$ sample counted previously to confirm that the AWCC was calibrated consistently.**

Each sample was counted for at least two $500 \mathrm{sec}$ intervals to check that instrument drifts were insignificant with respect to the counting statistics. Such drifts can be caused by temperature/humidity, Iine voltage, and similar effects. Efforts were made to minimize these. Each $\mathrm{U}_{3} \mathrm{O}_{8}$ sample in the scoping measurements was counted for at least two $500 \mathrm{sec}$ consecutive intervals, and all other samples were counted for at least four 500 sec consecutive intervals.

IV. AwCC Appraisal Studies with $\mathrm{U}_{3} \mathrm{O}_{8}$ Powders

\section{A. Preliminary scoping studies}

Initial tests with $\mathrm{U}_{3} \mathrm{O}_{8}$ samples in $\# 10$ and OSC cans, counted in AWCC geometry of Figure 2, were useful in defining parameters sensitive to neutron count rate $R$. It would have been ideal if $R$ were directly proportional to the mass of $\mathrm{u}-235$, or

$$
R=C^{\prime} m
$$

ॠ About $1 "$ shorter than \#10 can in Figure 2, and having a metal seal top (no polyurethane).

** During operator breaks, power down/up occurred sometimes during the day 
The scoping measurements (tabulated Appendix Tables A.I and A.2) for the \#10 and OSC samples show that equation (1) is approximately correct, as indicated in Figure 4. However, when plotting these results as $R / m=C^{\prime}$ vs. $m$, as shown in Figure $5, C^{\prime}$ is seen to be a decreasing function of $\mathrm{m}$. This implies that larger amounts of $\mathrm{U}-235$ have more self-shielding relative to the AmLi neutron sources, which in turn reduces the fission rate per $\mathrm{Kg}$ of $\mathrm{U}-235$ (or effectively, $\mathrm{R} / \mathrm{m}$ ).

Further examination of Figures 4 and 5 indicates that various data for these plots deviate significantly from any smooth average curves that represent the overall trends. However, uniform trends did exist for points having similar enrichment $e$, as indicated in the figures. Thus, in addition to the $\mathrm{m}$ dependence, $C^{\prime}$ is also dependent on $e$. Therefore, we can write

$$
R=C^{\prime}(m, e) m
$$

It should be noted that a different $C^{\prime}(m, e)$ will result for different types of $\mathrm{U}_{3} \mathrm{O}_{8}$ containers in general, although no measurable effect was observed in these scoping studies. $C^{\prime}(m, e)$ may also depend weakly on the $U$ isotopics other than U-235, but these were not isolated in the present studies.8 Thus, we proceed to examine the $m$ and $e$ dependences alone.

For an unknown sample, the enrichment e will not usually be known; however, the total mass $M$ of $U_{3} O_{8}$ may be determined by weighing. Furthermore, because

where

$$
e=a(m / M)=a f
$$

we may write

$$
\begin{aligned}
& \mathrm{a}=\mathrm{U}_{3} \mathrm{O}_{8} \mathrm{~mol} \mathrm{wt} / \mathrm{U}_{3} \mathrm{~mol} \mathrm{wt} \\
& \mathrm{f}=\mathrm{m} / \mathrm{M}
\end{aligned}
$$

$$
\begin{aligned}
C^{\prime}= & C^{\prime}(f M, a f)=c(M, f) \\
& \quad-\text { or }- \\
R= & C(M, f) m=c(M, f) M f
\end{aligned}
$$


Thus, by measuring $R$ and $M$, we can calculate $f$ to obtain $m=M f$, provided that $c(m, f)$ has been established from calibration studies.

The detailed studies that follow were aimed at appraising whether equation (4), deduced via the above scoping studies, can be usefully defined for AWCC determination of U-235 in $\mathrm{U}_{3} \mathrm{O}_{8}$ powders.

\section{B. Detailed Calibration Studies}

Measurements for samples of known $\mathrm{U}_{3} \mathrm{O}_{8}$ and enrichment in \#10 cans were designed to establish how well equation (4) could be calibrated. Cans with $M=2.000,4.000,-\cdots-$, and 12.000 $\mathrm{Kg}$ of $\mathrm{U}_{3} \mathrm{O}_{8}$ and with $\mathrm{f}=0.329,0.411,0.494,0.578$, and 0.646 were studied. A can with depleted $\mathrm{U}_{3} \mathrm{O}_{8}(\mathrm{M}=12.00, \mathrm{f}=0.0014)$ was also studied. The data for these measurements are given in Table I (see Appendix Tables A.3 and A.4 for details). The AWCC counting geometry $f$ and $R$ vs. $m$ results are given in Figures 3 and 6 . The results compare reasonably with those from the scoping studies shown in Figure 4. The results that test equation (4) directly are shown in Figure 7, where $R$ vs. $f$ is given for each $M$.

are given by

The smooth curves in Figure 7 are fits to the data and

$$
R=153.3\left(1+1.214 e^{-f / 0.278}\right)\left(1+0.535 e^{-M / 3.28}\right) M F
$$

where

$$
\begin{aligned}
& \mathrm{R} \text { is in counts/sec } \\
& \mathrm{M} \text { is in } \mathrm{Rg} \\
& \mathrm{F} \text { is unitless }
\end{aligned}
$$

In addition, it is seen that equation (5) is equation (4) with

$$
C(M, f)=153.3\left(1+1.214 e^{-f / 0.278}\right)\left(1+0.535 e^{-M / 3.28}\right)
$$

Equation ( 6$)$ for $C(M, f)$ was deduced by examining the measured $C(M, f)=R / M f$ values summarized in Table II. The data suggest that $C(M, f)$ has a functional form of $c_{1}(M) c_{2}(f)$. tt To deduce the best representation of $C_{1}(M)$ and $C_{2}(f)$, the $C_{(M, f)}$ data were combined into the averages,

$$
\begin{aligned}
& C_{1}(M)=C(M, \bar{f}), \\
& C_{2}(f)=\overline{C(M}, \text { average of } 5 \text { average of } 6 \text {-cases for each } M \\
& \text {-cases for each } f
\end{aligned}
$$

\rceil This geometry was somewhat different from that of Figure 2, because the polyurethane lid was included.

t† By contrast, $C(M, f)$ was shown to be poorly represented by a functional form $C(\mathrm{Mf})=\mathrm{C}(\mathrm{m})$. 
M. L. HYDER/D - A. WARD

$-8=$

DPST $=81=828$

November 10,1981

The resulting $c_{1}(M)$ and $c_{2}(f)$ data are plotted in Figures 8 and 9 , and are fitted to the expressions:

$$
\begin{aligned}
& c_{1}(M)=187.7\left(1+0.535 \mathrm{e}^{-M / 3.28}\right) \\
& c_{2}(f)=168.9\left(1+1.214 \mathrm{e}^{-f / 0.278}\right)
\end{aligned}
$$

The constant factors in front of these expressions are dependent on the $f$ or $M$ values included in the averages, but the relative $M$ or $f$ dependencies given by the second factors are independent of the averaging method. Thus, we may write

$$
\begin{gathered}
C(M, f)=C_{O}\left(1+1.214 e^{-f / 0.278}\right)\left(I+0.535 e^{-M / 3.28}\right) \\
C_{O}=\frac{C(M, f)}{\left(1+1.214 e^{-f / 0.278}\right)\left(1+0.535 e^{-M / 3.28}\right)}
\end{gathered}
$$

By calculating a $C_{0}$ for each of the $30(M, f)$-cases, as shown in Table III, an average $\bar{C}_{0}=153.3 \pm 0.4$ was obtained.

The individual $c_{0}$ values are distributed about $\bar{c}_{0}$ with a standard deviation of 1.48 . As shown in Table IV, over half of the $C_{0}$ deviate from $\mathrm{C}_{0}$ by $\langle 1 \%$, but several larger deviations (max of 2.98 ) tend to raise the overall standard deviation. It is suspected that some of these larger deviations are associated with instrument instabilitiest, which may be reducible. Upon close examination, one should recognize that the 8 -deviations of $\mathrm{C}_{\mathrm{O}}$ from $\bar{C}_{0}$ are also the corresponding 8 -deviations between the measured $R$ values and those obtained with equation (5).

The nature of equation (5) suggests some theoretical dependencies that might be refined by neutron transport or Monte Carlo calculations.5,17 To a large degree, the count rate $R$ is proportional to the $235 \mathrm{U}$ mass $m=M f$. However, this mass is shielded from neutrons by a factor of $\left(1+1.214 e^{-f / 0.278}\right)$ due to enrichment effects and a factor of $\left(1+0.535 \mathrm{e}^{-\mathrm{M} / 3.28}\right)$ due to overall mass $M$. The exponential term in each factor is probably associated with the thermal neutron flux attenuation. The other term is constant (unity) and thus, is probably associated with the fast neutron flux, which is only weakly attenuated. Although the above two-group neutron flux treatment yielded a good model for $R$, as given by equation (5), a multigroup analysis might improve the curve fitting. A correction for isotopic effects on count rate could be included also. 8

$†$ Instabilities caused by temperature-humidity conditions, power line fluctuations, etc. 
Possible isotopic effects may have been observed in the depleted $\mathrm{U}_{3} \mathrm{O}_{8}$ sample, where the observed count rate of $20.4 \pm 1.8 / \mathrm{sec}$ is noticeably larger than the $5.9 \mathrm{c} / \mathrm{sec}$ predicted by equation (5).

\section{Reliability of the Method}

The reliability of measuring $235 \mathrm{U}$ mass $\mathrm{m}$ with the AWCC was appraised in terms of the precision and accuracy of the $R$ measurements. The detailed analysis involved numerous measurements for \#10 cans containing $\mathrm{M}=6.000 \mathrm{Kg}$ of $\mathrm{U}_{3} \mathrm{O}_{8}$ powder. Also, the agreement of $R$ measurements with the predictions of equation (5) are used.

The precision was examined for errors caused by counting statistics and sample distribution. The results for the $M=6.000$ $\mathrm{Kg}$ series of measurements (distributed over one month) are given in Figure 10. Data related to the comparison with equation (5) are given in Table IV.

In Figure $10 a$, the standard deviation of $R$ due to counting statistics $\sigma_{S}$ is compared with the total standard deviation $\sigma_{T}$, calculated as

$$
\sigma_{T}=\sqrt{\sum_{n}(R-\bar{R}) 2 / n-1}
$$

where

$$
\begin{aligned}
& \bar{R}=\text { average of } \mathrm{R} \text {-measurements } \\
& \mathrm{n}=\text { number of } \mathrm{R} \text {-measurements }
\end{aligned}
$$

Agreement between $\sigma_{\mathrm{T}}$ and $\sigma_{\mathrm{S}}$ is reasonably good, suggesting that counting error is dominant in the present measurements. $t$ For one case, $\sigma_{T}$ was significantly larger than $\sigma_{S}$; however, removing one deviant set of measurements resulted in much better agreement for this case. A detailed analysis of these measurements, relative to confidence levels, is given in Table $V$ and Appendix Table A.4. The average $\sigma_{T}$ error in $R$ was 0.698 , yielding a $95 \%$ confidence level error of $1.35 \%$. The corresponding average $\sigma_{S}$ error is $0.57 \%$, yielding a 958 confidence level error of $1.12 \%$. The $1-\sigma$ error, excluding counting statistics, is given by

$+R$ was measured with 2000 sec count times. For sufficiently longer count times, $\sigma_{S}$ may decrease relative to $\sigma_{T}$. 
M. L. HYDER/D. A. WARE

$\sigma_{0}=\sqrt{\sigma T^{2-} \sigma S^{2}}=0.398$, which would be $\approx \sigma T$ for count times $>10 x$ longer than $2000 \mathrm{sec}$. This $\sigma_{0}$ represents the ultimate precision one might expect from these studies.

In Figure 10b, two separate series of measurements, labeled $E$ and $F$, are compared. As each separate series involved measurements for identical samples (same $M$ and $f$ values), taken under similar conditions, these results were used to appraise whether $\mathrm{E}$ and $F$ fluctuations are correlated with laboratory conditions. In Figure $10 b$, the suspected correlated $E$ and $F$ values ${ }^{\dagger}$ of $\Delta R=R-\bar{R}$ are plotted against each other. The correlation coefficient for these data was calculated as

$$
\rho=\frac{\sum(R(E)-\bar{R}(E))(R(F)-\bar{R}(F))}{(n-1) \sigma(E) \sigma(F)}
$$

where

$$
\begin{aligned}
& R(X)=\text { count rate for series } X \text { measurement. } \\
& \bar{R}(X)=\text { count rate for series } X \text { average. } \\
& \sigma(X)=\text { standard deviation for } X \text { in Figure } 10 \mathrm{~b} . \\
& n \quad=\text { number of points in Figure } 10 \mathrm{~b} .
\end{aligned}
$$

The resulting $\rho=0.3$ indicates that a weak correlation did exist. Probably drifts in detector efficiency due to temperature-humidity effects, detector voltage setting, etc. are contributing to the overall correlation. Later measurements in this series addressed some of these effects, suggesting that $o$ can be kept small so that the uncorrelated statistical counting error will dominate. Correlated errors can also be reduced by daily normalization corrections using a known standard $\mathrm{U}_{3} \mathrm{O}_{8}$ sample.

In Figure 10c, the sample-to-sample precision of purported identical $(M, f)$-cases for $E$ and $F$ series measurements are appraised. Here $\Delta=R(E)-R(F)$ are compared. Agreement between $\Delta$ and 0.0 is good, being distributed within $2 \sigma_{\Delta} \approx 0.58$ of the measurement error. $t^{t}$. Thus, no noticeable additional error was exhibited for sample preparation effects such as weighings, can geometry consistency, etc.

$\dagger$ Values measured within a few hours of each other

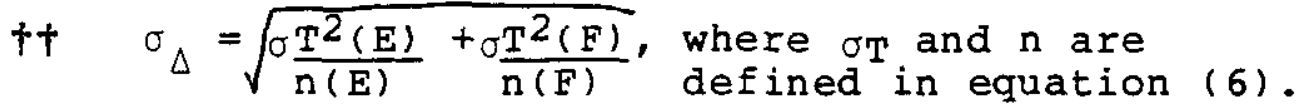


M. L. HYDER/D. $\bar{A}$. WARD $\cdots-11-\cdots$

November 10,1981

The accuracy was investigated by assuming that systematic errors are given by deviations from a smooth fit to the $R$ vs $f$ plot for the well-studied $M=6.000 \mathrm{~kg}$ data.t The statistical average of the 14 or 15 measurements for each point has a statistical error of $<0.38$. Deviations beyond this are systematic in part. As shown in Figure 11, such deviations are $<18$, and the average RMS deviation is 0.68 .

The above examination of precision and accuracy suggests what may be feasible under optimal measurement conditions. The overall precision and accuracy demonstrated by the present work is not considered optional, but was estimated by examining the average deviation in $C_{0}$ (equivalently $R$ ) for each $M$ or $f$, as shown in Table IV. These average deviations, $D C_{0} \pm \sigma\left(D C_{0}\right)$, are used to estimate accuracy with the $\mathrm{DC}_{\mathrm{o}}$ values and precision with the $\sigma\left(D C_{O}\right)$ values. The $D C_{O}$, which are averages of $C_{0}$ deviations from equation (5), should be $0.0 \%$ if systematic errors are absent.

The $D C_{\circ}$ values are from -0.98 to +0.98 , and have a RMS average of 0.608 . The $\sigma\left(D_{0}\right)$ values range from 0.58 to 2.08 , with an RMS average of $1.3 \%$ (corresponding to $95 \%$ confidence level of 2.58$)$.

In sum, it is seen that all measurements of $R$ are consistent with having a systematic error of $\sim 0.68$, and that statistical errors can be reduced well below 18 with suitable counting times and good measurement conditions.

The reliability for m measurements must be deduced from the precision and accuracy of the $\mathrm{R}$ measurements. Assuming that reliable accuracy can be afforded with a good set of calibration standards, the above discussion implies that, under good measurement conditions, the limiting error will be governed by the counting statistics. The discussion that follows will apply to the $2000 \mathrm{sec}$ counts used in this study.

The statistical precision for $R$ measurements is summarized in the $\sigma_{S}$ vs $R$ plot of Figure 12. Here, the counting error $\sigma_{S}$ is relatively insensitive to true coincidence rate $R$, because $R$ is the difference in two large count rates - the "trues plus randoms"

$\mp$ The $M=6.000 \mathrm{Kg}$ data above yield $C_{0}=154.6$, per fit to equation (5). 
M. L. HYDER/D. A. WARD

$-12-$

DPST-81-828

November 10,1981

minus "randoms". By setting $R=S$, we predict the standard deviation $m$ in the $235 \mathrm{U}$ measurement as

$$
\begin{aligned}
& \sigma_{m}=\sqrt{\left(\frac{\partial m}{\partial R} \sigma_{R}\right)^{2}+\left(\frac{\partial m}{\partial M} \sigma_{M}\right)^{2}} \\
& \sigma_{m} \approx \frac{\partial m}{\partial R} \sigma_{R}
\end{aligned}
$$

where the error $M$ in the total $U_{3} O_{8}$ is small. A more convenient representation of equation (7), is

$$
\begin{aligned}
& \sigma_{m}=\quad \frac{\partial m}{\partial R} \sigma_{R}=\frac{\partial(f M)}{\partial R} \sigma_{R}=\frac{M \sigma_{R}}{\partial R / \partial f} \\
& \text { - Or - } \\
& \frac{\sigma_{m}}{m}=\frac{\sigma_{R}}{f \partial R / \partial f}
\end{aligned}
$$

By differentiating equation (5) for $\partial R / \partial f$, we obtain

$$
\frac{\sigma_{m}}{m}=\frac{\sigma_{R}}{R}\left(1-\frac{1.214(f / 0.278)}{e^{f / 0.278+1.214}}\right)^{-1}
$$

The $\sigma_{m} / m$ results are plotted against $m$ in Figure 13 . A quick appraisal of equation ( 8 ) shows that the 8 errors $\sigma_{\mathrm{m}} / \mathrm{m}$ and $\sigma_{\mathrm{R}} / \mathrm{R}$ are not too different, since $f \partial R / \partial f \approx R$ from equation ( 9 ) and Figure $4 . \dagger$ This provides a useful guide for appraising the counting statistics required for a given $235 \mathrm{U}$ measurement.

Figure 13 indicates that measurements for $m>1.0 \mathrm{Kg}$ can be made to precision of 18 with 2000 sec counts, but the error increases rapidly for smaller $\mathrm{m}$. The results also indicate that measurements for a large sample are preferable to summing the measurements of smaller components of this sample, as the accuracy and counting times are more favorable. (In effect, each component contributes its own random-coincidence background, so that the

$\dagger$ A detailed analysis using equation (9) shows $0.67 R<f \frac{\partial R}{\partial f}<R$. 
total background correction error is larger.) This contrasts with the typical low-background nuclear statistical error, where either approach yields essentially the same error.t Theoretical correlations for the statistical errors have been developed. 6

\section{AWCC Measurements on Test Samples}

\section{A. $\mathrm{U}_{3} \mathrm{O}_{8}$ Powder Samples}

A test $\mathrm{U}_{3} \mathrm{O}_{8}$ sample in a \#10 can was weighed $(M=10.225 \mathrm{Kg})$ and counted in the $A W C C(R=730.3 \pm 3.4 / \mathrm{sec}=$ average of four 2000 sec counts). Using equation (5), values of $f=0.333 \pm 0.002$ and $\mathrm{m}=3.406 \pm 0.023 \mathrm{~kg}$ were calculated, where the errors correspond to the counting error above.

Mass spectroscopy measurements for the same sample indicate $\mathrm{m}=3.347 \pm 0.021 \mathrm{Kg}$, which differs from the AWCC value by $1.7 \pm 0.9 \%$, which is consistent with the deviations shown in Table IV. Thus, the AWCC and mass spec values agree to within $2 \sigma=1.8 \%$.

The above result implies that equation (5), which is used to calculate $\mathrm{m}$, is not accurate enough to assure $\mathrm{m}$ determinations accurate to $\sim 18$ with 958 confidence level. However, it appears that improved techniques, using a combination of measurements and Monte Carlo calculations, 5,17 can provide better calibration curves, as well as reducing the number of calibration measurements required.

\section{B. New Brunswick Test Samples}

Results for the NBL samples are given in Appendix Table A.5. The 2000 sec measurements of each the $0.0 \mathrm{gm}$ and $125.35 \mathrm{gm} 235_{\mathrm{U}}$ samples yielded $-8 \pm 4 \mathrm{gm}$ and $140 \pm 7 \mathrm{gm}$, where the errors are $\sigma_{\mathrm{S}}$. (The corresponding $\sigma_{\mathrm{T}}$ were respectively $\pm 14 \mathrm{gm}$ and $\pm 20 \mathrm{gm}$.$) These results were calculated using equation (5).$ Although agreement is reasonable with respect to $\sigma_{S}$ and $\sigma_{T}$, the associated $z$-error is $>10 \%$, which is not surprising in view of the

+ Assuming we get $N \pm \sqrt{N}$ counts for a sample in time $t$, we break the sample into $n$ smaller samples and obtain $N_{i} \pm \sqrt{N_{i}}$ counts for the ith sample in time $t$. The total count for all $n$ samples is then

$$
\begin{gathered}
\sum\left(N_{i} \pm N_{i}\right)=\left(\sum N_{i}\right) \pm \sqrt{\sum\left(\sqrt{N_{i}}\right)^{2}}=\left(\sum N_{i}\right)+\sqrt{\Sigma N_{i}} \\
N \pm \sqrt{N}
\end{gathered}
$$


M. L. HYDER/D.A. WARD

$-14=-128$

November 10,1981

error projected in Figure 13. On the other hand, the above agreement is better than that reported earlier for these measurements, 14 prior to the development of equation (5).

\section{300-Area Scrap Samples}

The AWCC measurements for the 300-Area scrap samples are summarized in Appendix Table A.6. Each sample was measured with four $2000 \mathrm{sec}$ counts. The 235 $\mathrm{U}$ content was then determined using equation (5). The AWCC values for the two heavier samples agreed to $\sim 28$ of the known $235 \mathrm{U}$ content, but the AWCC values for the four lighter samples were all low by 20-408.

It is questionable whether the data were reliable for the four lighter samples, as $\sigma_{T}$ for each was considerably larger than $\sigma_{S}$, suggesting unstable operating conditions. Some of the measurements for each of these samples were taken on the same date; however, a calibration measurement on this date reproduced the count rate obtained earlier for a $6.00 \mathrm{~kg}$ sample. Because each sample was not moved during the four 2000 sec counts, the $\sigma_{T}$ should not have been dramatically larger than the $\sigma_{S}$.

The questionable low count rates may have resulted in high voltage breakdown in the detectors. Thus, assuming that the largest 2000 sec count rate for each sample may have been more representative, the results were recalculated, as shown in Table A.6. The agreement was within $15 \%$ for all cases except one (which disagreed by 268), but all values were still low. It may be that geometrical distribution effects of the $235 \mathrm{U}$ in the sample are being noticed. A future reexamination of these or similar samples is needed to completely resolve these discrepancies. $f$

\section{Conclusions}

These studies demonstrate a feasibility for using the AWCC to measure $235 \mathrm{U}(\mathrm{m}>1 \mathrm{Kg})$ in $\mathrm{U}_{3} \mathrm{O}_{8}$ to an accuracy of 18 , provided that stable measurement conditions are maintained and that calibration curves defined by equation (3) have been established for the AWCC counting geometry used. This performance may be accomplished with several $2000 \mathrm{sec}$ counts of a sample; however, good temperature, humidity, and electrical conditions should be assured by calibration tests with a standard sample of $\mathrm{U}_{3} \mathrm{O}_{8} \cdot$

$\mp$ Unfortunately, the AWCC had been scheduled for return to LASI before, these discrepancies were fully appreciated. 

M. L. HYDER/D. A. WARD

The performance was not as good for the New Brunswick standards and the 300-Area scrap samples.13-16 In these cases, with $235 \mathrm{U}<1 \mathrm{Kg}$, a 2000 sec count yielded significantly worse accuracy. For example, a $400 \mathrm{gm}$ sample would be measured with a 1- precision of only 38 , and a counting time of at least $18,000 \mathrm{sec}$ or $5 \mathrm{hrs}$ would be required to improve the precision to 18 . For smaller samples, the situation is even more severe. Also, for nonuniform samples, the shielding effects can cause systematic errors, which were not examined in this work. Thus, the described method is not strongly recommended for measuring samples with $500 \mathrm{gm}$, or samples with known non-uniformities in shielding. On the other hand, the method has been modified to work better for low $235 \mathrm{U}$ samples, by removing the cd shielding to improve the thermal neutron fission rate.2,7 However, any effects due to non-uniformities would be increased with the more absorbant thermal neutrons. Overall, the method works best for large samples of $235^{U}$, both in terms of accuracy and counting times. 


\section{$\underline{\text { References }}$}

1. Howard O. Menlove, "Description and Operation Manual for Active Well Coincidence Counter," Los Alamos Scientific Laboratory report LA-7823-M (May 1979).

2. H. O. Menlove, N. Ensslin, C. R. Hatcher, E. Medina, and J. Foley, "Active Well Coincidence Counter," Los Alamos Scientific Laboratory report LA-7211-PR (1977) pp. 7-10.

3. Merlyn Stewart Krick and Howard O. Menlove, "The High-Level Neutron Coincidence Counter (HLNCC): Users' Manual," Los Alamos Scientific Laboratory report LA-7779-M (1978).

4. Howard O. Menlove, Norbert Ensslin, and Thomas E. Sampson, "Experimental Comparison of the Active Well Coincidence Counter with the Random Driver," Los Alamos Scientific Laboratory report LA-7882-MS (June 1979).

5. Howard O. Menlove and Gerald E. Bosler, "Application of the Active Well Coincidence Counter (AWCC) to High-Enrichment Uranium Metal," Los Alamos Scientific Laboratory report LA-8621-MS (August 1981).

6. J. E. Swansen, N. Ensslin, M. S. Krick, and H. O. Men love, "A New Shift Register for High Count Rate Coincidence Applications," Los Alamos Scientific Laboratory report LA-6788-PR (1977).

7. Nuclear Safeguards Research Program Status Report, January March 1979, Los Alamos Scientific Laboratory report LA-7801-PR (June 1979), p. 42-44.

8. T. W. Crane, "Test and Evaluation Results of the $252 \mathrm{Cf}$ Shuffler at the Savannah River Plant," Los Alamos Scientific report LA-8755-MS (March 1981).

9. J. H. Owen (Memorandum to S. P. Rideout), "Californium Shuffler," June 15, 1981.

10. N. Ensslin, P. Collinsworth, W. L. Belew, R. S. Thomson, and P. Deason, "Uranium Assays at SRP with the AWCC Neutron Detector," (in preparation).

11. Nuclear Safeguards Research Program Status Report, July Sept 1980, Los Alamos Scientific Laboratory report LA-8590-PR (March 1981), p. 21-23. 
12. H. B. Peacock, "Powder Metallurgy at Savannah River Laboratory," DP-1524 (December 1978).

13. Letter, N. H. Seebeck to J. H. Owen, "Measurement of U-235 Content in NBL Standards," June 5, 1981.

14. E. T. Booth (memorandum to Ann Gibbs), "Evaluation of New Brunswick Standards with Active Well Coincidence Counter," July 23, 1981

15. J. H. Owen (memorandum to R. S. Swingle, II), "U-235 for SRL Evaluation of AWCC," May 21, 1981.

16. RTA No. 1-SP/SG, "Additional Evaluation of AWCC for Assay of $235 \mathrm{U}$ in Small Quantity (25 to $400 \mathrm{gm}$ )."

17. Gerald E. Bosler, "Analytical Techniques to Reduce the Number of Physical Standards Needed for Neutron Coincidence Counter," LOS Alamos Scientific Laboratory report LA-8509-MS (July 1981).

18. E. T. Booth (memorandum to D. A. Ward), "Safety Evaluation of Active Well Coincidence Counter," DPST-81-337, March 24, 1981 .

19. James E. Swanson, Paul R. Collinsworth, and Merlyn Krick, "Shift Register Coincidence Electronics system for Thermal Neutron Counter," Nuclear Instruments and Methods 176 $(1980), 555-565$. 
TABLE I. COUNT RATE $R$ FOR $\mathrm{U}_{3} \mathrm{O}_{8}$ MEASUREMENTS ${ }^{\mathrm{a}}$

\begin{tabular}{cccccc}
\hline $\begin{array}{l}M=\text { mass } \mathrm{U}_{3} \mathrm{O}_{8} \\
(\mathrm{Kg})\end{array}$ & .3285 & .4106 & .4940 & .5777 & .6464 \\
\hline 12.0 & 848.9 & 953.6 & 1116.3 & 1257.1 & 1348.2 \\
10.0 & 703.0 & 815.3 & 929.2 & 1036.5 & 1141.3 \\
8.0 & 570.8 & 671.1 & 765.5 & 852.1 & 903.1 \\
6.0 & 455.8 & 524.0 & 600.3 & 675.5 & 726.0 \\
4.0 & 325.8 & 373.3 & 433.2 & 460.3 & 512.9 \\
2.0 & 174.8 & 203.5 & 239.8 & 271.1 & 287.2 \\
\hline
\end{tabular}

a) Detailed studies, using AWCC geometry of Figure 3 .

b) R measured using 22000 sec count time. See Appendix Tables A. 3 and A.4 for details. 
$\underline{\text { TABLE II. R/MF FOR U } \mathrm{U}_{3} \mathrm{O}_{8} \text { MEASUREMENTS }}$

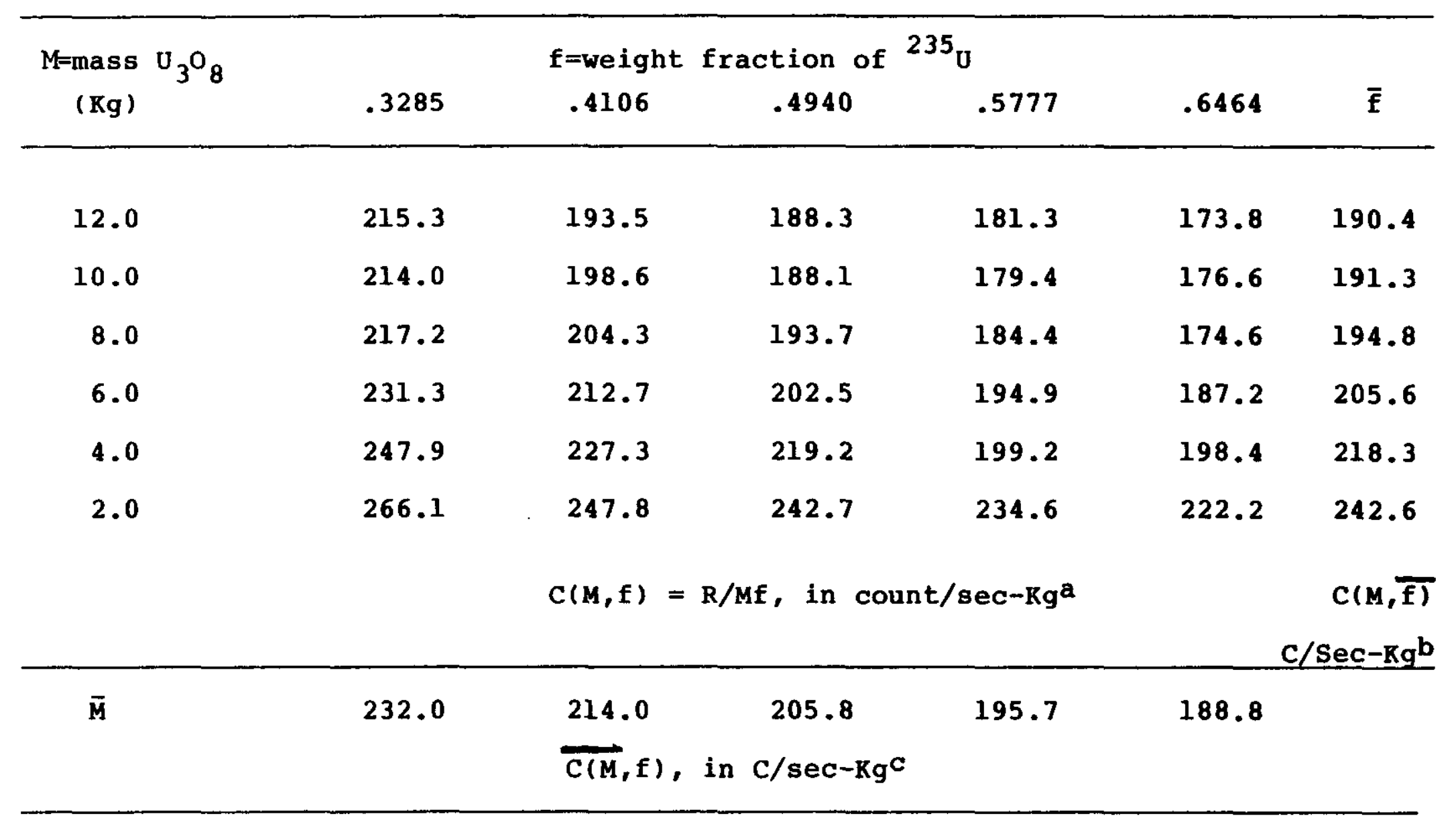

a) Calculated from results in Table I

b) Plotted vs $M$ in Figure 8

c) Plotted vs $f$ in Figure 9 
TABLE III. $\mathrm{C}_{0}$ FOR U $\mathrm{U}_{3} \mathrm{O}_{8}$ MEASUREMENTS

\begin{tabular}{rlcccc}
\hline $\begin{array}{c}M=\text { mass } \mathrm{U}_{3} \mathrm{O}_{8} \\
(\mathrm{Kg})\end{array}$ & .3285 & .4106 & .4940 & .5777 & .6464 \\
\hline 12.0 & 154.8 & 149.5 & 154.1 & 155.3 & 153.3 \\
10.0 & 152.1 & 151.6 & 152.2 & 151.9 & 153.9 \\
8.0 & 151.2 & 152.8 & 153.5 & 152.9 & 149.1 \\
6.0 & 155.2 & 153.4 & 154.7 & 155.8 & 154.1 \\
4.0 & 156.0 & 153.7 & 157.1 & 149.3 & 153.1 \\
2.0 & 150.2 & 150.3 & 156.0 & 157.8 & 153.9 \\
& & & & $\mathrm{c}_{0}=153.3 \pm 0.4$ \\
\hline
\end{tabular}

a) $C_{0}$ calculated with equation $(5 b)$, using $C(M, f)$ from Table II. 
TABLE IV. $\left(\mathrm{C}_{0}-\overline{\mathrm{C}}_{0}\right)$ FOR $\mathrm{U}_{3} \mathrm{O}_{8}$ MEASUREMENTS

\begin{tabular}{|c|c|c|c|c|c|c|}
\hline $\begin{array}{l}M=\operatorname{mass} \\
(\mathrm{Kg})\end{array}$ & .3285 & $\begin{array}{l}f=\text { weight } \\
.4106\end{array}$ & $\begin{array}{r}\text { raction } \\
.4940\end{array}$ & $\begin{array}{l}235 \mathrm{v} \\
.5777\end{array}$ & .6464 & $\overline{\mathbf{f}}$ \\
\hline 12.0 & 1.0 & -2.5 & 0.5 & 1.3 & -0.0 & $-0.1 \pm 1.4$ \\
\hline 10.0 & -0.8 & -1.1 & -0.7 & -0.9 & 0.4 & $-0.6 \pm 0.5$ \\
\hline 8.0 & -1.4 & -0.3 & 0.2 & -0.2 & -2.7 & $-0.9 \pm 1.1$ \\
\hline 6.0 & 1.2 & 0.0 & 0.9 & 1.6 & 0.5 & $0.8 \pm 0.6$ \\
\hline 4.0 & 1.8 & 0.3 & 2.5 & -2.6 & -0.1 & $0.4 \pm 1.8$ \\
\hline 2.0 & -2.0 & -1.9 & 1.8 & 2.9 & 0.4 & $0.2 \pm 2.0$ \\
\hline \multicolumn{6}{|c|}{$c_{0}-\bar{c}_{0}$, in 8} & \multirow{2}{*}{$\begin{array}{c}D C_{O} \\
\pm \sigma\left(D C_{o}\right)\end{array}$} \\
\hline$\overline{\mathbf{M}}$ & $0.0 \pm 1.4$ & $-0.9 \pm 0.9$ & $0.9 \pm 0.9$ & $0.4 \pm 1.8$ & $-0.3 \pm 1.1$ & \\
\hline
\end{tabular}

a) $\mathrm{C}_{\mathrm{O}}-\overline{\mathrm{C}}_{\mathrm{O}}$ in $z$ of $\overline{\mathrm{C}}_{\mathrm{O}}$, using data of Table III. Note: these deviations are the same as $R-R(f i t)$, where $R(f i t)$ is given by equation (5). 
TABLE V. STATISTICAL ANALYSIS FOR $6 \mathrm{kgm} \mathrm{U3O_{8 }}$ MEASUREMENTS

\begin{tabular}{|c|c|c|c|c|c|c|c|}
\hline $\mathbf{f}$ & Series & $\overline{\mathrm{R}}\left(\operatorname{Sec}^{-1}\right)$ & $n^{b}$ & $\sigma_{\mathrm{T}}(18)$ & $\rho(<18)^{c}$ & $\rho(<28)$ & $\rho(<38)$ \\
\hline 0.3285 & $\begin{array}{c}\mathbf{E} \\
\mathbf{F} \\
\mathbf{E} \& \mathbf{F}\end{array}$ & $\begin{array}{l}454.95 \\
456.63 \\
455.7\end{array}$ & $\begin{array}{r}8 \\
7 \\
15\end{array}$ & $\begin{array}{l}0.64 \\
0.78 \\
0.71\end{array}$ & $\begin{array}{l}0.88 \\
0.80 \\
0.84\end{array}$ & $\begin{array}{l}1.00 \\
0.99 \\
1.00\end{array}$ & $\begin{array}{l}1.00 \\
1.00 \\
1.00\end{array}$ \\
\hline 0.4106 & $\begin{array}{c}\mathbf{E} \\
\mathbf{F} \\
\mathbf{E} \& \mathbf{F}\end{array}$ & $\begin{array}{l}524.09 \\
523.98 \\
524.0\end{array}$ & $\begin{array}{r}8 \\
7 \\
15\end{array}$ & $\begin{array}{l}0.79 \\
0.60 \\
0.69\end{array}$ & $\begin{array}{l}0.79 \\
0.90 \\
0.85\end{array}$ & $\begin{array}{l}0.99 \\
1.00 \\
1.00\end{array}$ & $\begin{array}{l}1.00 \\
1.00 \\
1.00\end{array}$ \\
\hline 0.4940 & $\begin{array}{c}E \\
F \\
E \& F\end{array}$ & $\begin{array}{l}600.19 \\
600.35 \\
600.3\end{array}$ & $\begin{array}{r}7 \\
7 \\
14\end{array}$ & $\begin{array}{l}0.43 \\
0.64 \\
0.52\end{array}$ & $\begin{array}{l}0.98 \\
0.88 \\
0.94\end{array}$ & $\begin{array}{l}1.00 \\
1.00 \\
1.00\end{array}$ & $\begin{array}{l}1.00 \\
1.00 \\
1.00\end{array}$ \\
\hline 0.5777 & $\begin{array}{c}\mathbf{E} \\
\mathbf{F} \\
\mathbf{E} \& \mathbf{F}\end{array}$ & $\begin{array}{l}676.42 \\
674.61 \\
675.5\end{array}$ & $\begin{array}{r}7 \\
7 \\
14\end{array}$ & $\begin{array}{l}0.95 \\
0.83 \\
0.87\end{array}$ & $\begin{array}{l}0.71 \\
0.77 \\
0.75\end{array}$ & $\begin{array}{l}0.96 \\
0.98 \\
0.97\end{array}$ & $\begin{array}{l}1.00 \\
1.00 \\
1.00\end{array}$ \\
\hline $0.5777^{d}$ & $\begin{array}{c}\mathbf{E} \\
\mathbf{F} \\
\mathbf{E} \& \mathbf{F}\end{array}$ & $\begin{array}{l}677.01 \\
676.36 \\
676.7\end{array}$ & $\begin{array}{r}5 \\
5 \\
10\end{array}$ & $\begin{array}{l}0.50 \\
0.61 \\
0.53\end{array}$ & $\begin{array}{l}0.95 \\
0.90 \\
0.93\end{array}$ & $\begin{array}{l}1.00 \\
1.00 \\
1.00\end{array}$ & $\begin{array}{l}1.00 \\
1.00 \\
1.00\end{array}$ \\
\hline 0.6464 & $\begin{array}{c}\mathbf{E} \\
\mathbf{F} \\
\mathbf{E} \& \mathbf{F}\end{array}$ & $\begin{array}{l}728.07 \\
723.91 \\
726.0\end{array}$ & $\begin{array}{r}7 \\
9 \\
16\end{array}$ & $\begin{array}{l}0.36 \\
0.62 \\
0.58\end{array}$ & $\begin{array}{l}0.99 \\
0.89 \\
0.92\end{array}$ & $\begin{array}{l}1.00 \\
1.00 \\
1.00\end{array}$ & $\begin{array}{l}1.00 \\
1.00 \\
1.00\end{array}$ \\
\hline $0.6464^{d}$ & $\begin{array}{c}\mathbf{E} \\
\mathbf{F} \\
\mathbf{E} \& \mathbf{F}\end{array}$ & $\begin{array}{l}728.07 \\
725.24 \\
726.7\end{array}$ & $\begin{array}{r}7 \\
7 \\
14\end{array}$ & $\begin{array}{l}0.36 \\
0.30 \\
0.37\end{array}$ & $\begin{array}{l}0.99 \\
1.00 \\
0.99\end{array}$ & $\begin{array}{l}1.00 \\
1.00 \\
1.00\end{array}$ & $\begin{array}{l}1.00 \\
1.00 \\
1.00\end{array}$ \\
\hline
\end{tabular}

a) Refer to Appendix Table A.4 for detailed data.

b) $n=$ number of measurements used to calculate $\vec{R}$ and $\sigma_{T}$. (See equation (5).)

c) $\rho(\varepsilon)$ is probability that a single measurement will be within $\pm \varepsilon$ of true value, where

$$
\rho(\varepsilon)=\frac{1}{\sqrt{2 \pi}} \int_{-\varepsilon}^{\varepsilon} e^{-x^{2} / 2 \sigma_{T}} d x
$$

d) Suspicious measurements deleted. 


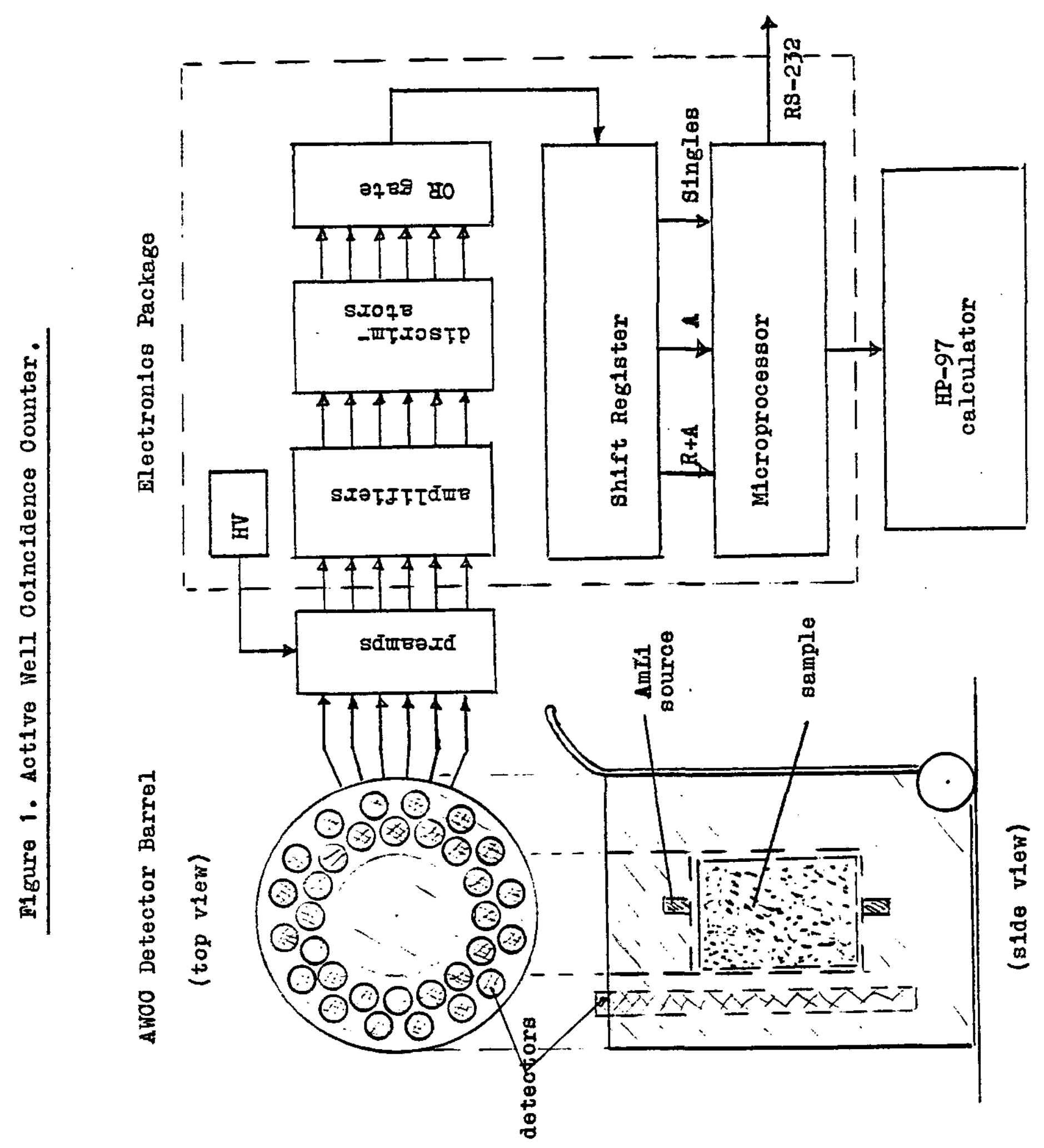


, , . .

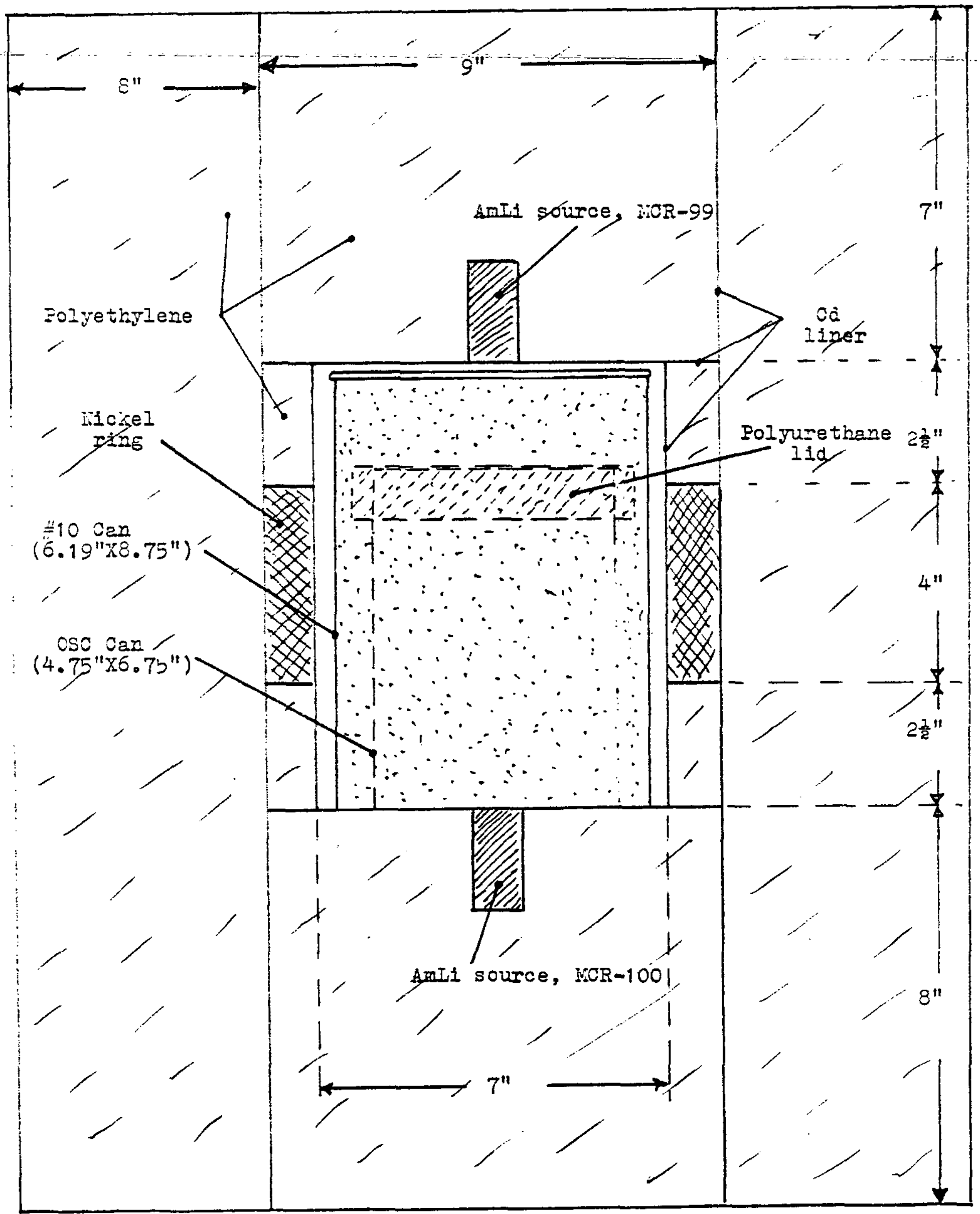

F1 gux 2. Airco geometry for scoping studies on U308. 


\section{$R=A$ ANCC count rate, counts $/ \mathrm{sec}$}

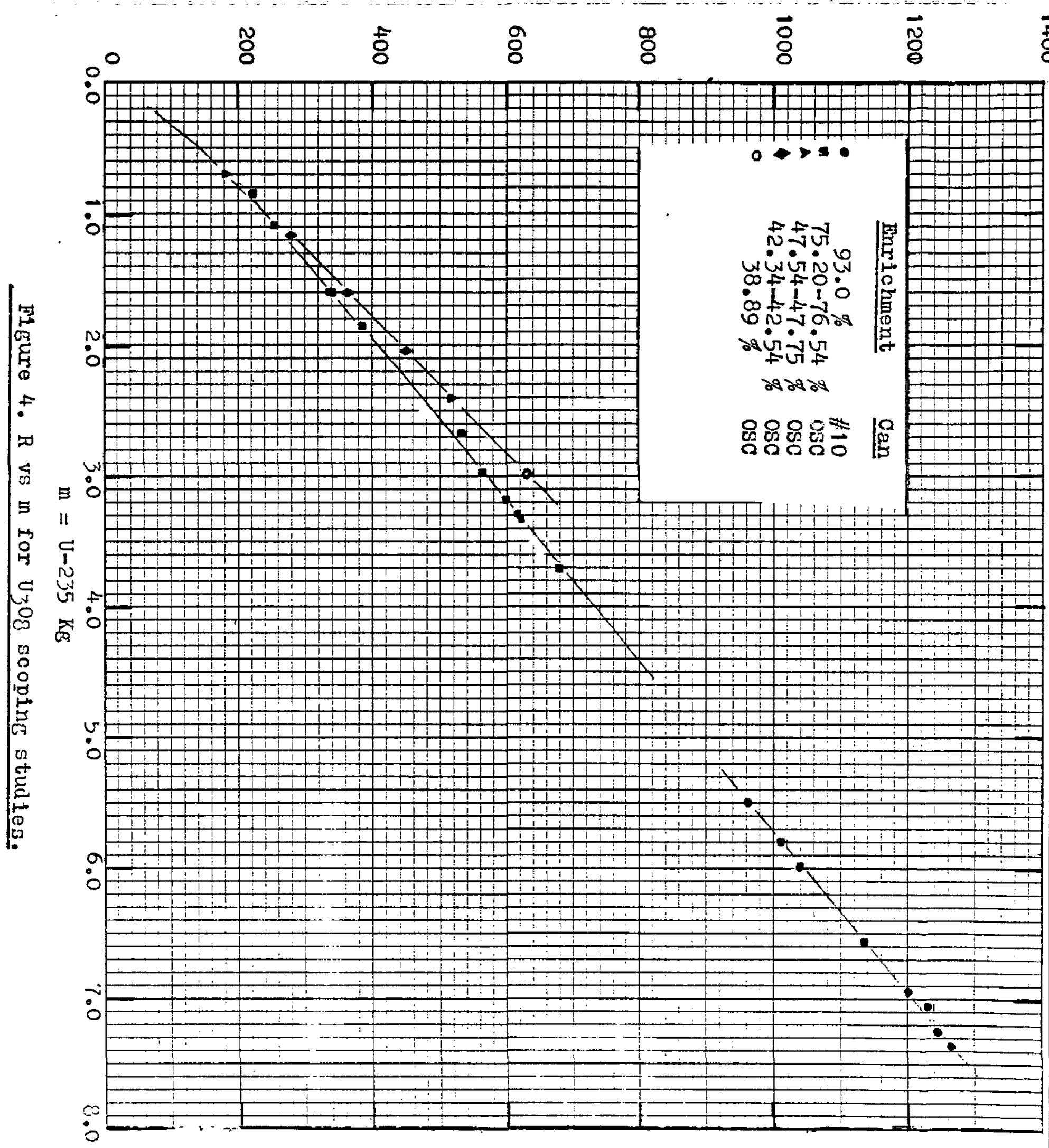


$\mathrm{R} / \mathrm{II}=\mathrm{AHCC}$ count rate $/ \mathrm{U}-235$, counts $/$ sec- $\mathrm{K}_{\mathrm{B}}$

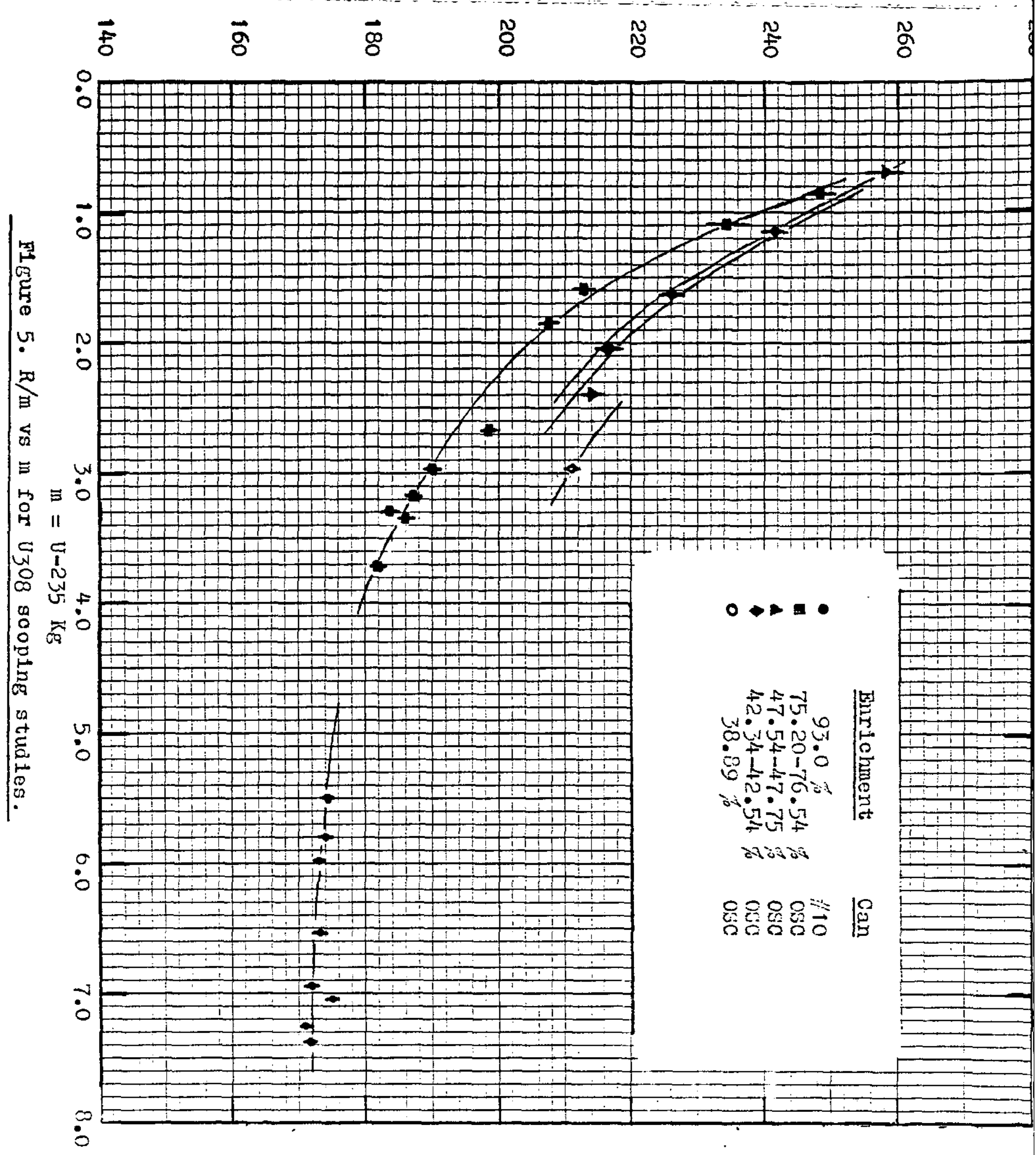


$R=A W C C$ count rate, counts $/$ sec

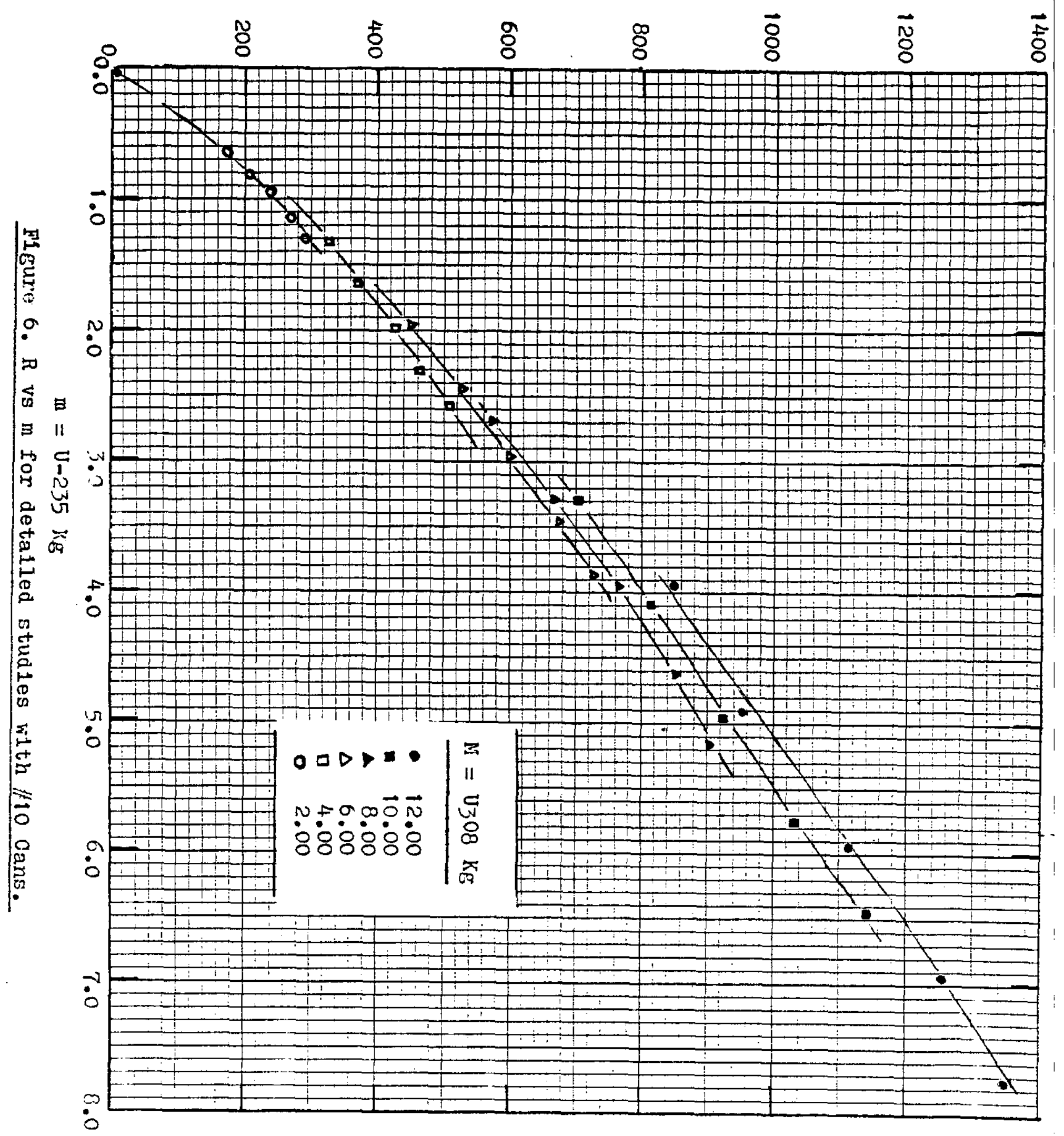


$R=$ AirCC count rate, counts/sec

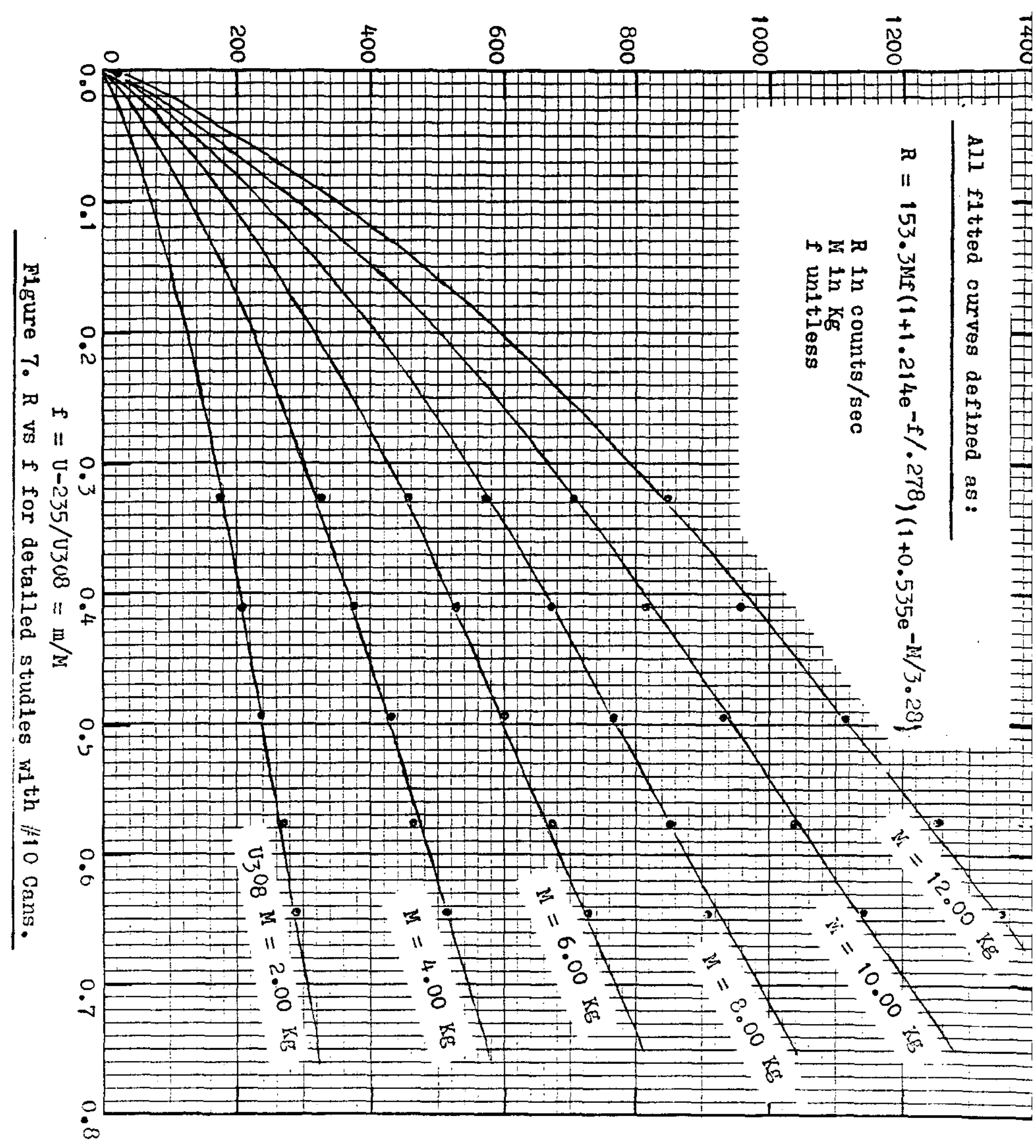




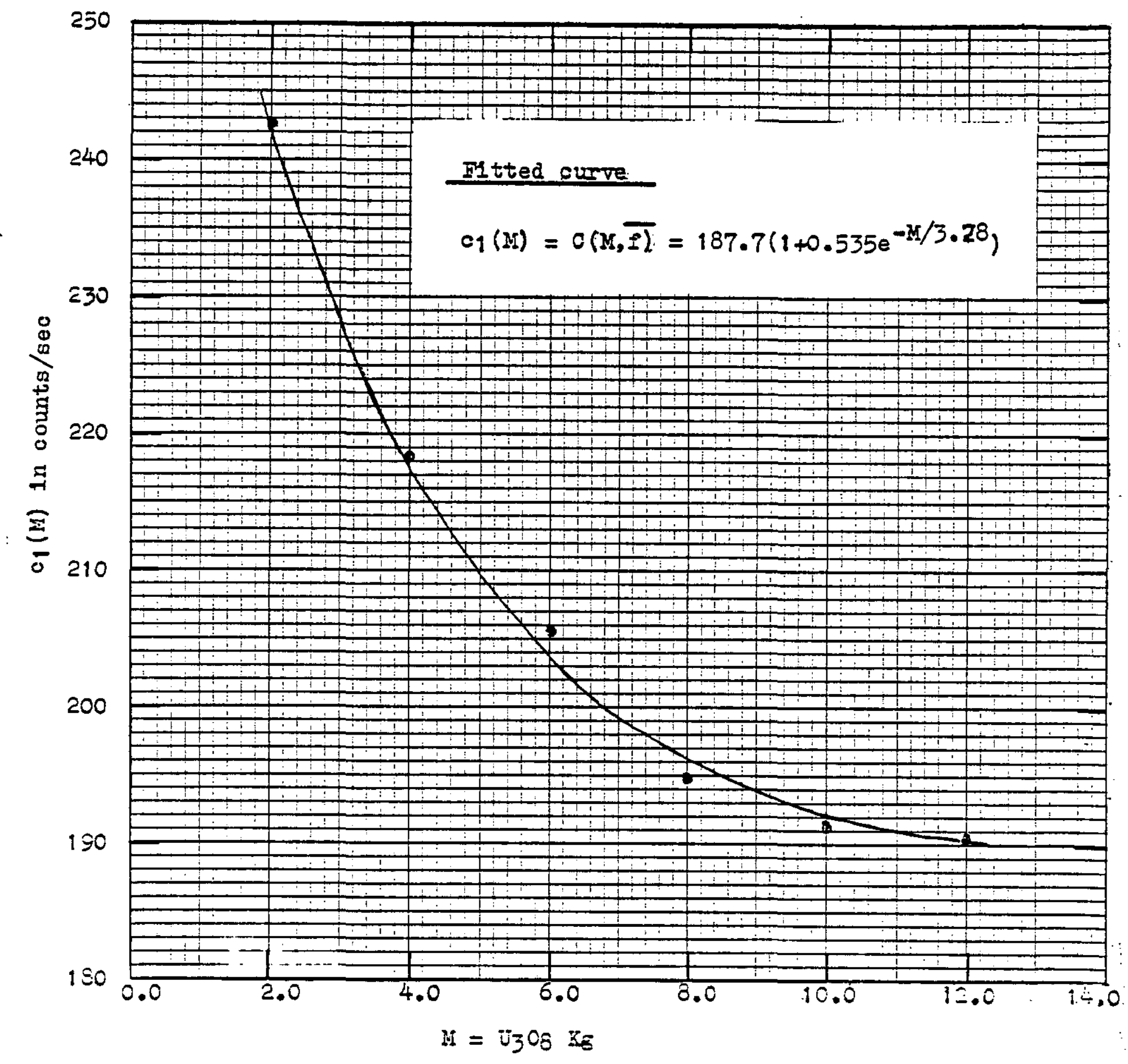

P1gure 8. cq (ï) vs Mi from detalled jjo8 stuales. 


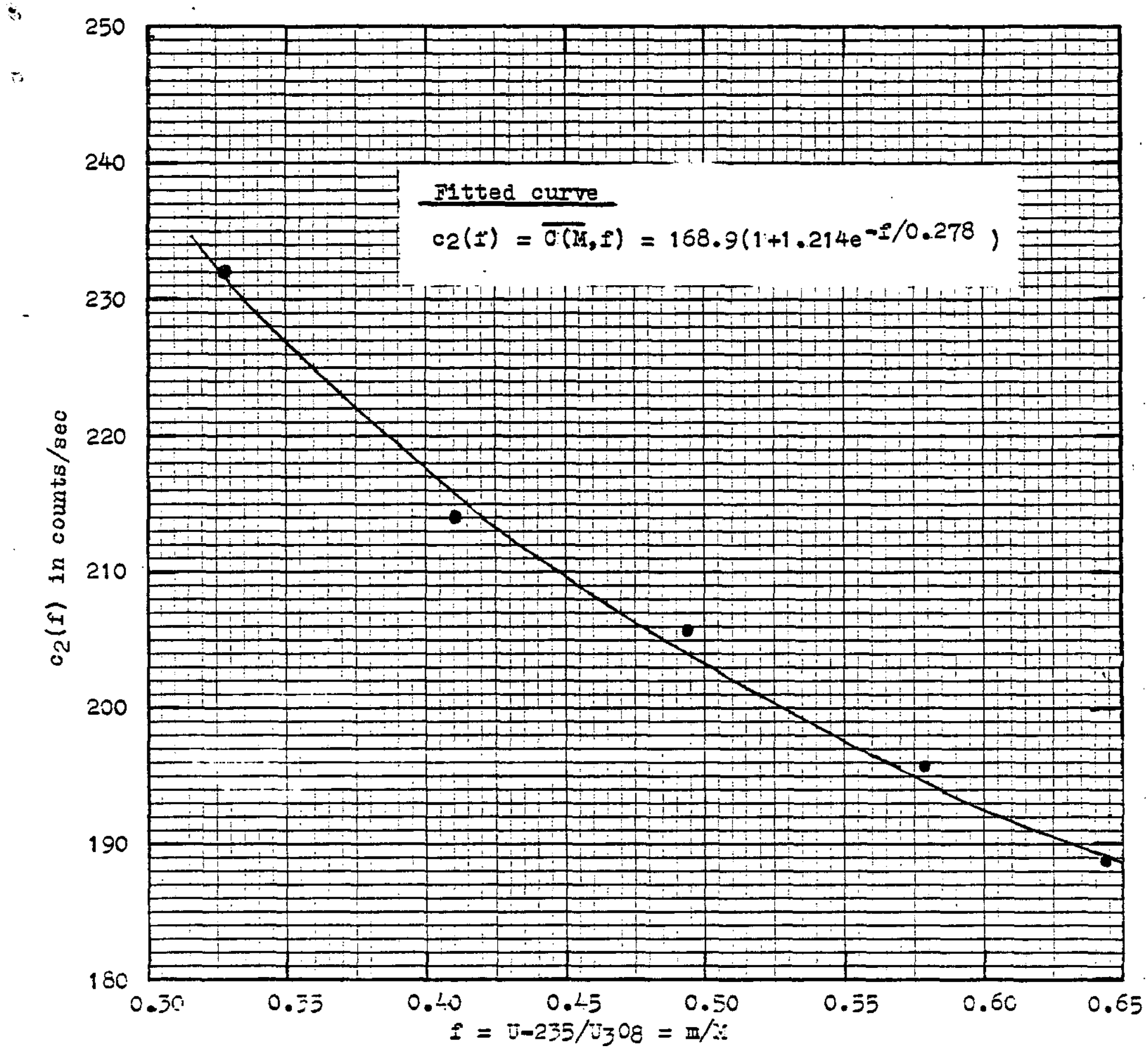

Flgure 9. $c_{2}(I)$ VS $\mathrm{I}$ for detalled $\mathrm{H}_{3} \mathrm{O}_{\mathrm{g}}$ stucies. 


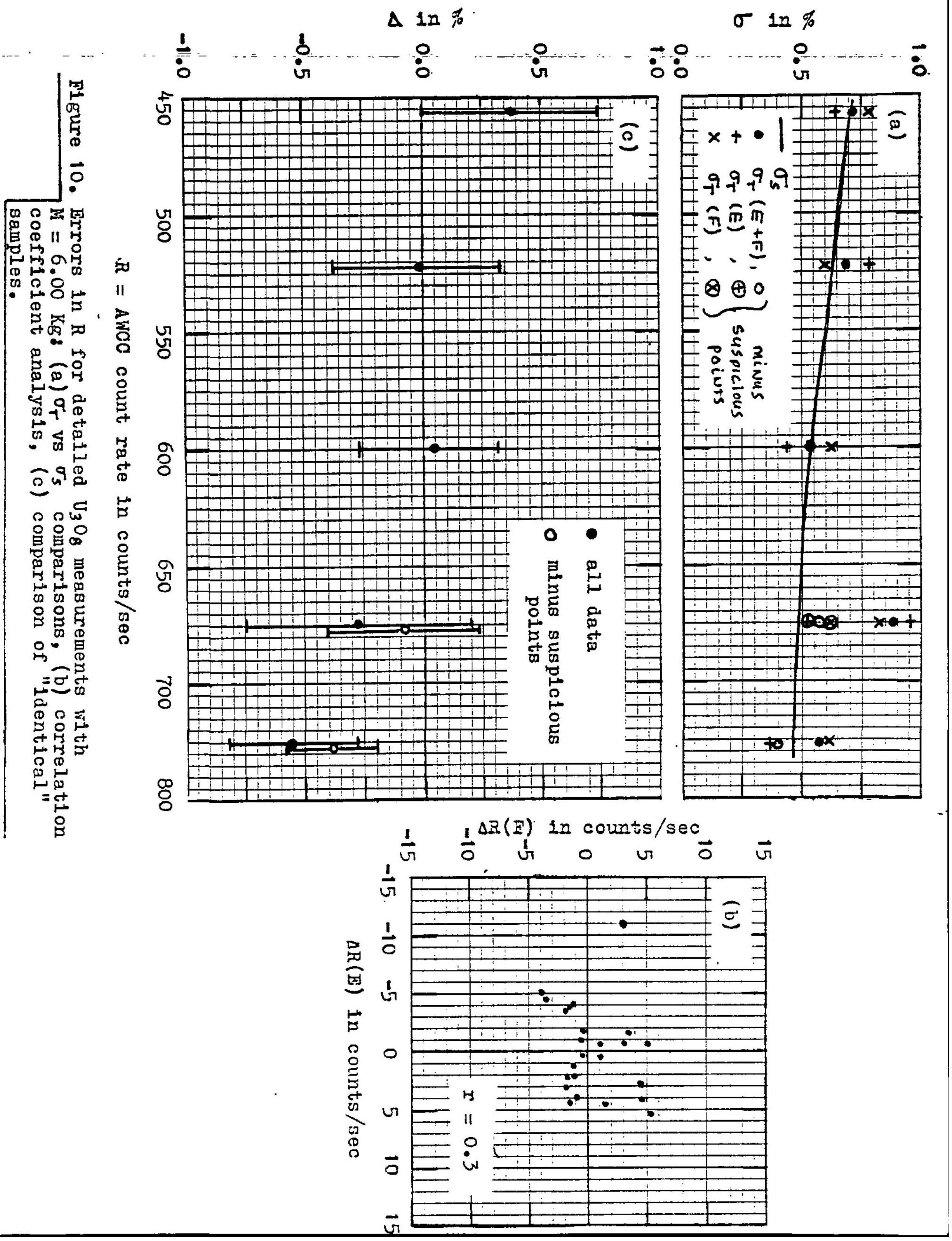




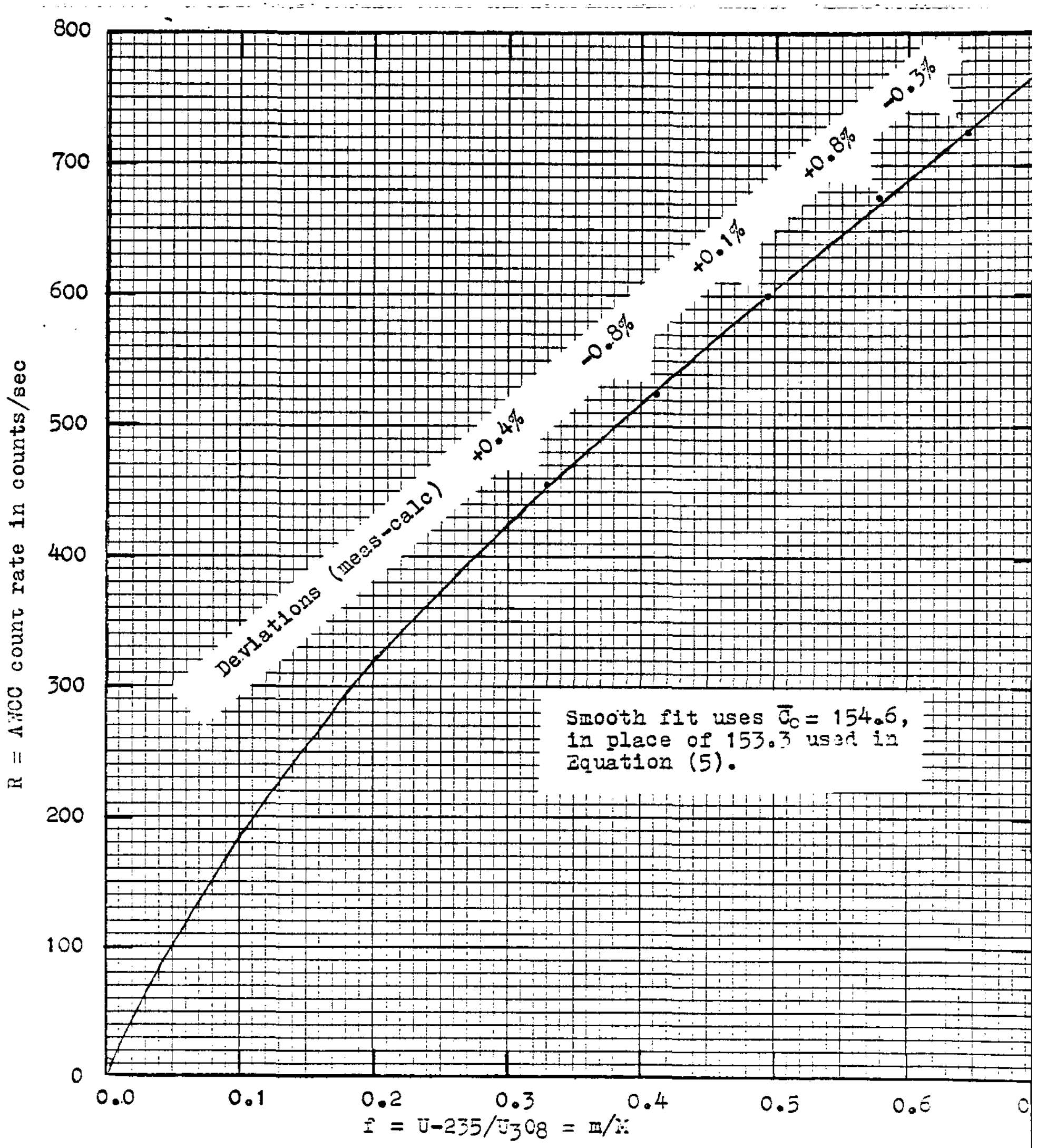

Iigure 11. a vS $f$ for $10 \mathrm{Cans}$ w1th $\mathrm{N}=0.00 \mathrm{Kz}$. 
$\sigma_{S}=\sigma$ due to countins statisties, in counts/sec

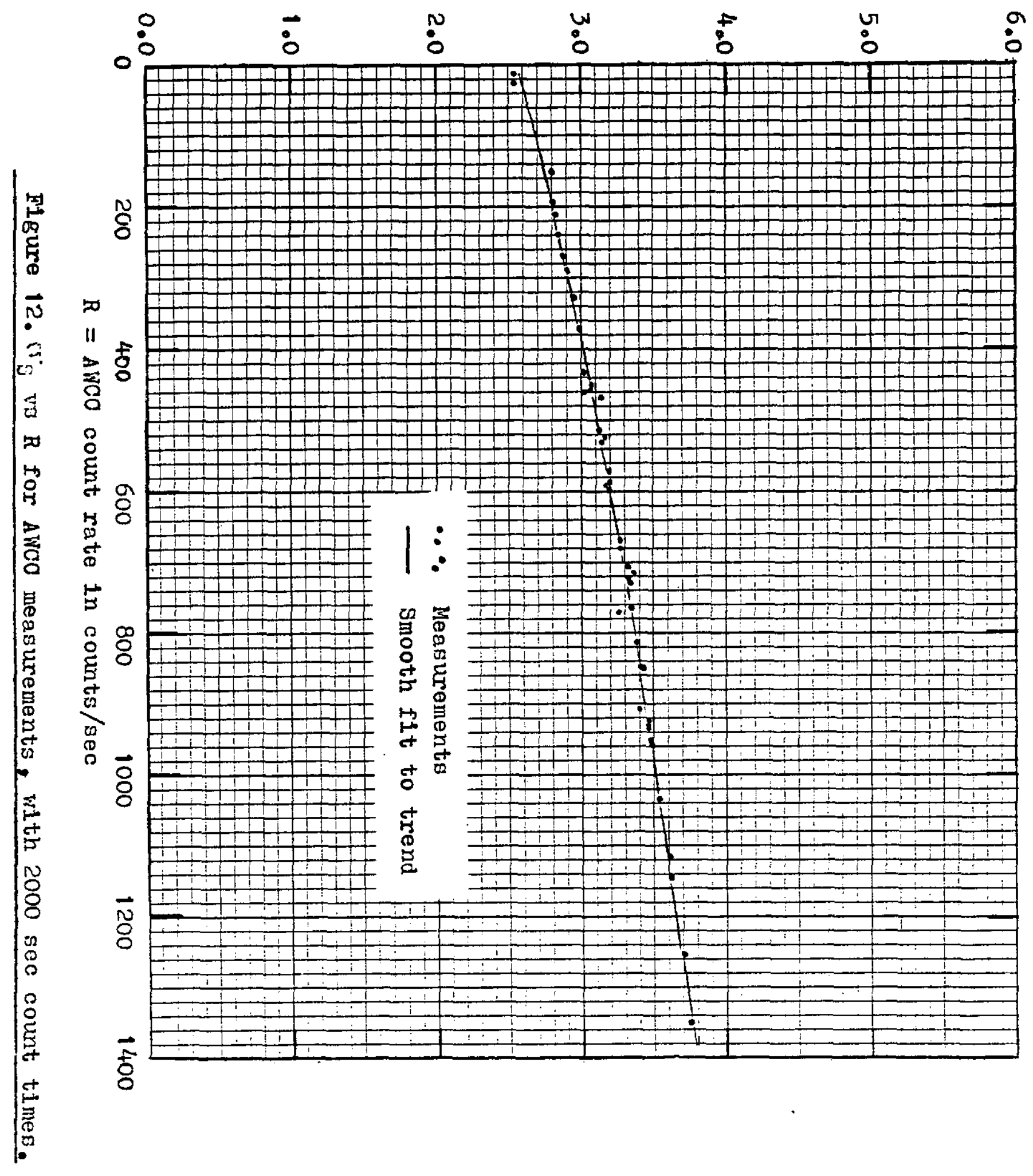


$\sigma_{\text {m }}$ in $\%$ of II

'十

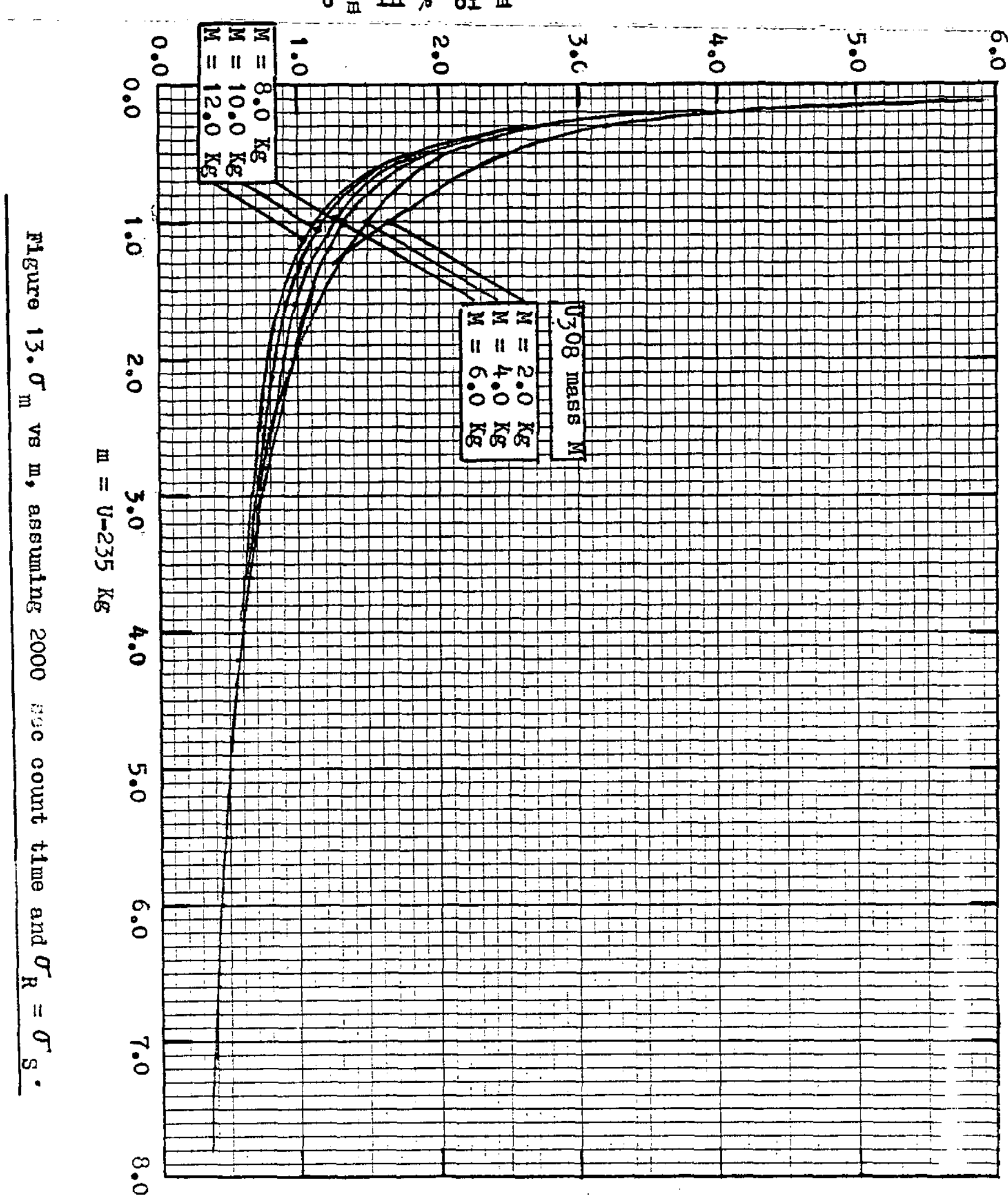


Data taken in these studies are presented for the convenience of other AWCC researchers. A guide for using these tables is presented below:

\section{All Data Tables}

- $R$ is given in counts per sec statistical counting error $\sigma \mathrm{s}$.

- Count times for $R$ measurements are given as $n x t i$, where $n$ individual count intervals of duration $t i$ are summed for the total count time.

Tables A.1 and A.2

- Data from scoping studies

Table A.3

- Data from Detailed studies

- $\mathrm{E}=\mathrm{wt}{ }^{235_{\mathrm{U}} / \mathrm{wt} \mathrm{U}_{3} \mathrm{O}_{8}}$

\section{Table A.4}

- Data for extensive $6.0 \mathrm{Kg}$ sample tests

- $\mathrm{f}=\mathrm{wt} 235_{\mathrm{U} / \mathrm{wt}} \mathrm{U}_{3} \mathrm{O}_{8}$

- Series refer to one of two "identical" $6.0 \mathrm{Kg}$ samples

$$
\begin{aligned}
& \text { E } \\
& F
\end{aligned}
$$

$E+F \quad \bar{R}$, etc. based on both $E$ and $F$

$E, F \quad \vec{R}$ estimated as $[\bar{R}(E)+\bar{R}(F)] / 2$

- Date refers to time of measurement 
- Analysis insert boxes

$\bar{R}$ average $R$

$\sigma_{S}$ counting error of $R$

$\bar{\sigma}_{S}$ counting error of $\bar{R}$

$\sigma_{T}$ measured standard deviation for $R$

$\bar{\sigma} T$ measured standard deviation for $\bar{R}$

$$
\Delta=\left(\bar{R} \pm \bar{\sigma}_{T}\right)_{F}-\left(\bar{R} \pm \bar{\sigma}_{T}\right)_{E}
$$

Tables A.5 and A.6

- Data for New Brunswick Samples/Scrap Samples-300 Area

- Sample mass is used as $M$ in analyses 
TABLE A.1 SCOPING STUDIES- \#10 CANS (SEALED-NO POLYURETHANE LID)

\begin{tabular}{|c|c|c|c|c|}
\hline${ }^{235} \mathrm{U}$ Enrichment & $\mathrm{O}_{3} \mathrm{O}_{8}$ & ${ }^{235} \mathrm{v}$ & $\underline{R}$ & Count Time \\
\hline 8 & $\mathrm{Kg}$ & Rg & $c / s$ & nxti, sec \\
\hline 93 & 6.995 & 5.493 & $959.0 \pm 2.7$ & $6 \times 500$ \\
\hline 93 & 7.370 & 5.807 & $1010.9 \pm 4.6$ & $2 \times 500$ \\
\hline 93 & 7.608 & 5.982 & $1038.9 \pm 6.6$ & $2 \times 500$ \\
\hline 93 & 8.347 & 6.570 & $1134.7 \pm 4.8$ & $2 \times 500$ \\
\hline 93 & 8.834 & 6.741 & $1195.5 \pm 4.8$ & $2 \times 500$ \\
\hline 93 & 8.954 & 7.040 & $1230.4 \pm 4.8$ & $2 \times 500$ \\
\hline 93 & 9.210 & 7.268 & $1242.9 \pm 4.9$ & $2 \times 500$ \\
\hline 93 & 9.368 & 7.372 & $1265.4 \pm 4.9$ & $2 \times 500$ \\
\hline
\end{tabular}




\begin{tabular}{|c|c|c|c|c|}
\hline${ }^{235} \mathrm{U}$ Enrichment & $\underline{\mathrm{U}_{3} \mathrm{O}_{8}}$ & $235_{0}$ & $\mathbf{R}$ & Count Time \\
\hline 8 & $\mathbf{K g}$ & Kg & $c / s$ & nxti, sec \\
\hline 38.87 & 9.085 & 2.982 & $629.3 \pm 3.3$ & $3 \times 500$ \\
\hline 42.34 & 3.265 & 1.167 & $281.8 \pm 2.4$ & $4 \times 500$ \\
\hline 42.36 & 5.772 & 2.065 & $448.1 \pm 2.8$ & $4 \times 500$ \\
\hline 42.54 & 4.498 & 1.619 & $366.7 \pm 1.9$ & $8 \times 500$ \\
\hline 47.45 & 1.744 & 0.699 & $180.6 \pm 2.3$ & $4 \times 500$ \\
\hline 47.45 & 5.980 & 2.414 & $517.4 \pm 3.1$ & $3 \times 500$ \\
\hline 75.20 & 2.970 & 1.855 & $385.1 \pm 2.6$ & $4 \times 500$ \\
\hline 75.47 & 1.359 & 0.851 & $211.4 \pm 1.7$ & $8 \times 500$ \\
\hline 75.50 & 4.753 & 2.976 & $565.4 \pm 3.2$ & $3 \times 500$ \\
\hline 75.51 & 4.285 & 2.684 & $532.4 \pm 3.1$ & $3 \times 500$ \\
\hline 75.94 & 2.503 & 1.596 & $339.9 \pm 2.5$ & $4 \times 500$ \\
\hline 75.94 & 4.995 & 3.185 & $597.4 \pm 3.3$ & $3 \times 500$ \\
\hline 75.94 & 5.219 & 3.328 & $620.1 \pm 3.3$ & $3 \times 500$ \\
\hline 76.54 & 1.690 & 1.092 & $256.2 \pm 3.4$ & $2 \times 500$ \\
\hline 76.54 & 5.104 & 3.298 & $613.1 \pm 4.1$ & $2 \times 500$ \\
\hline 76.54 & 5.766 & 3.726 & $678.5 \pm 3.0$ & $4 \times 500$ \\
\hline
\end{tabular}




\begin{tabular}{|c|c|c|c|c|c|}
\hline $\mathrm{U}_{3} \mathrm{O}_{8}$ & ${ }^{235} \mathrm{U}$ & $\underline{E}$ & ${ }^{235} \mathrm{U}$ Enrichment & $\mathbf{R}$ & Count Time \\
\hline $\mathrm{Kg}$ & $\mathrm{Kg}$ & $\#$ & 8 & $c / s$ & nxti, sec \\
\hline 2.000 & 0.657 & 0.3285 & 38.89 & $174.8 \pm 2.8$ & $4 \times 500$ \\
\hline 2.000 & 0.821 & 0.4106 & 48.61 & $203.5 \pm 2.0$ & $8 \times 500$ \\
\hline 2.000 & 0.988 & 0.4940 & 58.65 & $239.8 \pm 2.8$ & $4 \times 500$ \\
\hline 2.000 & 1.155 & 0.5777 & 68.71 & $271.1 \pm 2.9$ & $4 \times 500$ \\
\hline 2.000 & 1.292 & 0.6464 & 76.54 & $287.2 \pm 2.9$ & $4 \times 500$ \\
\hline 3.999 & 1.314 & 0.3285 & 38.89 & $325.8 \pm 2.4$ & $8 \times 500$ \\
\hline 4.000 & 1.642 & 0.4106 & 48.61 & $373.3 \pm 2.5$ & $4 \times 500$ \\
\hline 4.003 & 1.976 & 0.4940 & 58.65 & $433.2 \pm 3.0$ & $4 \times 500$ \\
\hline 4.000 & 2.311 & 0.5777 & 68.71 & $460.3 \pm 3.0$ & $4 \times 500$ \\
\hline 4.000 & 2.585 & 0.6464 & 76.54 & $512.9 \pm 3.1$ & $4 \times 500$ \\
\hline 5.998 & 1.971 & 0.3285 & 38.89 & $455.8 \pm 0.8$ & $\operatorname{many} y^{a}$ \\
\hline 5.999 & 2.463 & 0.4106 & 48.61 & $524.0 \pm 0.8$ & $\operatorname{many} y^{a}$ \\
\hline 6.000 & 2.964 & 0.4940 & 58.65 & $600.3 \pm 0.9$ & $\operatorname{man} y^{a}$ \\
\hline 6.000 & 3.464 & 0.5777 & 68.71 & $675.5 \pm 0.9$ & $\operatorname{man} y^{a}$ \\
\hline 6.000 & 3.877 & 0.6464 & 76.54 & $726.0 \pm 0.8$ & $\operatorname{man} y^{a}$ \\
\hline
\end{tabular}

a) See Table A.4 for details 


\begin{tabular}{|c|c|c|c|c|c|}
\hline $\mathrm{U}_{3} \mathrm{O}_{8}$ & ${ }^{235} \mathrm{U}$ & $\mathbf{f}$ & ${ }^{235} \mathrm{U}$ Enrichment & $\mathbf{R}$ & Count Time \\
\hline $\mathrm{Kg}$ & $\mathrm{Kg}$ & \# & 8 & $\mathrm{c} / \mathrm{s}$ & nxti, sec \\
\hline 7.998 & 2.628 & 0.3285 & 38.89 & $570.8 \pm 2.0$ & $11 \times 500$ \\
\hline 7.998 & 3.284 & 0.4106 & 48.61 & $671.1 \pm 3.3$ & $4 \times 500$ \\
\hline 8.003 & 3.940 & 0.4940 & 58.65 & $765.5 \pm 3.3$ & $4 \times 500$ \\
\hline 7.999 & 4.621 & 0.5777 & 68.71 & $852.1 \pm 3.4$ & $4 \times 500$ \\
\hline 8.000 & 5.170 & 0.6464 & 76.54 & $903.1 \pm 3.4$ & $4 \times 500$ \\
\hline 10.000 & 3.285 & 0.3285 & 38.89 & $703.0 \pm 3.3$ & $4 \times 500$ \\
\hline 10.000 & 4.106 & 0.4106 & 48.61 & $815.3 \pm 3.4$ & $4 \times 500$ \\
\hline 10.003 & 4.942 & 0.4940 & 58.65 & $929.2 \pm 2.4$ & $8 \times 500$ \\
\hline 10.000 & 5.777 & 0.5777 & 68.71 & $1036.5 \pm 3.5$ & $4 \times 500$ \\
\hline 10.000 & 6.462 & 0.6464 & 76.54 & $1141.3 \pm 3.6$ & $4 \times 500$ \\
\hline 12.000 & 3.942 & 0.3285 & 38.89 & $848.9 \pm 3.4$ & $4 \times 500$ \\
\hline 12.000 & 4.927 & 0.4106 & 48.61 & $953.6 \pm 2.5$ & $8 \times 500$ \\
\hline 12.003 & 5.929 & 0.4940 & 58.65 & $1116.3 \pm 3.6$ & $4 \times 500$ \\
\hline 12.000 & 6.933 & 0.5777 & 68.71 & $1257.1 \pm 3.7$ & $4 \times 500$ \\
\hline 12.000 & 7.754 & 0.3285 & 76.54 & $1348.2 \pm 3.7$ & $4 \times 500$ \\
\hline 12.000 & 0.0173 & 0.0014 & 0.17 & $20.4 \pm 1.8$ & $8 \times 500$ \\
\hline
\end{tabular}


TABLE A.4 EXTENSIVE TESTS WITH $6 \mathrm{~kg}$ SAMPLES

$\frac{{ }^{235} \mathrm{U} \text { Enrich. }}{8}$

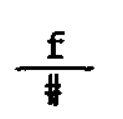

$\frac{{ }^{235} \mathrm{U}}{\mathrm{Kg}}$

0.3285

1.971

\begin{tabular}{|c|c|c|c|c|c|}
\hline \multirow[b]{2}{*}{ Series } & \multicolumn{4}{|c|}{ ANALYSIS } & \multirow[b]{2}{*}{$\bar{\sigma}_{T}$} \\
\hline & 只 & $\sigma_{S}$ & $\bar{\sigma}_{S}$ & $\sigma_{\mathrm{T}}$ & \\
\hline $\begin{array}{c}E \\
F \\
E \& F \\
E, F\end{array}$ & $\begin{array}{l}454.95 \\
456.63 \\
455.7 \\
455.8\end{array}$ & $\begin{array}{l}3.13 \\
3.13 \\
3.13\end{array}$ & $\begin{array}{l}\overline{1.11} \\
1.19 \\
0.81\end{array}$ & $\begin{array}{l}2.92 \\
3.58 \\
3.25\end{array}$ & $\begin{array}{l}1.03 \\
1.35 \\
0.84\end{array}$ \\
\hline $\begin{aligned} \Delta & = \\
& =\end{aligned}$ & $\begin{array}{l}\left(\bar{R} \pm \bar{\sigma}_{T}\right. \\
1.68 \pm\end{array}$ & $\begin{array}{l}-1 \\
.69\end{array}$ & $\left.\bar{\sigma}_{T}\right)_{E}$ & $v^{\circ}$ & \\
\hline
\end{tabular}

48.61

0.4106

2.463

ANALYSIS

\begin{tabular}{|c|c|c|c|c|c|}
\hline \multicolumn{6}{|c|}{ ANALYSIS } \\
\hline Series & $\bar{R}$ & ${ }^{\sigma_{S}}$ & $\bar{\sigma}_{S}$ & $\sigma_{T}$ & $\bar{\sigma}_{\mathrm{T}}$ \\
\hline $\begin{array}{c}E \\
F \\
E \& F \\
E, F \\
\Delta= \\
=\end{array}$ & $\begin{array}{l}524.09 \\
523.98 \\
524.0 \\
524.0 \\
\left(R \pm \bar{\sigma}_{T}\right) \\
.11 \pm 1\end{array}$ & $\begin{array}{l}3.18 \\
3.18 \\
3.18 \\
-(\bar{R} \\
.89\end{array}$ & $\begin{array}{l}1.12 \\
1.20 \\
0.82 \\
\left. \pm \bar{\sigma}_{T}\right)\end{array}$ & $\begin{array}{l}4.15 \\
3.17 \\
3.59\end{array}$ & $\begin{array}{l}1.46 \\
1.20 \\
0.93\end{array}$ \\
\hline
\end{tabular}

Series

$\mathbf{E}$
$\mathbf{E}$
$\mathbf{E}$
$\mathbf{E}$
$\mathbf{E}$
$\mathbf{E}$
$\mathbf{E}$
$\mathbf{E}$
$\mathbf{F}$
$\mathbf{F}$
$\mathbf{F}$
$\mathbf{F}$
$\mathbf{F}$
$\mathbf{F}$
$\mathbf{F}$

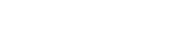

\section{$\frac{R}{c / s}$}

$454.5 \pm 3.1$

$455.6 \pm 3.1$

$453.7 \pm 3.1$

$458.1 \pm 3.1$

$450.0 \pm 3.1$

$452.4 \pm 3.1$

$456.7 \pm 3.2$

$458.6 \pm 3.2$

$461.5 \pm 3.1$

$457.6 \pm 3.1$

$460.2 \pm 3.1$

$453.2 \pm 3.1$

$455.6 \pm 3.1$

$457.0 \pm 3.2$

$451.4 \pm 3.2$

$530.2 \pm 3.1$

$529.5 \pm 3.1$

$521.8 \pm 3.2$

$525.0 \pm 3.2$

$518.0 \pm 3.2$

$523.2 \pm 3.2$

$524.2 \pm 3.2$

$520.9 \pm 3.2$

$529.3 \pm 3.1$

$519.3 \pm 3.1$

$523.9 \pm 3.2$

$523.6 \pm 3.2$

$525.0 \pm 3.2$

$525.3 \pm 3.2$

$521.5 \pm 3.2$ $\frac{\text { Count Time }}{\text { nxti,sec }}$

Date

m/d781

$4 \times 500$
$4 \times 500$
$4 \times 500$
$4 \times 500$
$1 \times 2000$
$1 \times 2000$
$1 \times 2000$
$1 \times 2000$
$4 \times 500$
$4 \times 500$
$4 \times 500$
$1 \times 2000$
$1 \times 2000$
$1 \times 2000$
$1 \times 2000$
$4 \times 500$
$4 \times 500$
$4 \times 500$
$4 \times 500$
$1 \times 2000$
$1 \times 2000$
$1 \times 2000$
$1 \times 2000$
$4 \times 500$
$4 \times 500$
$4 \times 500$
$1 \times 2000$
$1 \times 2000$
$1 \times 2000$
$1 \times 2000$

$5 / 8$

$5 / 13$

$5 / 19$

$5 / 20$

$6 / 4$

$6 / 4$

$6 / 10$

$6 / 10$

$5 / 8$

$5 / 13$

$5 / 19$

$6 / 4$

$6 / 4$

$6 / 10$

$6 / 10$

$5 / 7$

$5 / 8$

$5 / 13$

$5 / 19$

$5 / 28$

$5 / 28$

$6 / 10$

$6 / 10$

$5 / 8$

$5 / 13$

$5 / 19$

$6 / 2$

$6 / 2$

$6 / 10$

$6 / 10$ 
㞫

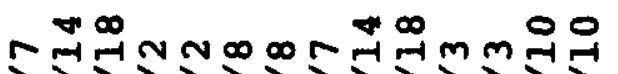
ก ก

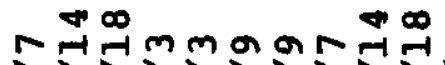

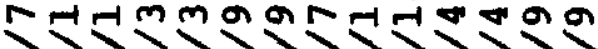

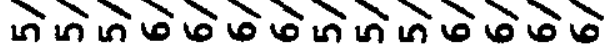

Uี

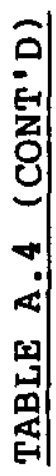

N $N N N m m N N N m$ $\dot{m} \dot{m} \dot{m} \dot{m} \dot{m} \dot{m} \dot{m} \dot{m} \dot{m} \dot{m} \dot{m}$

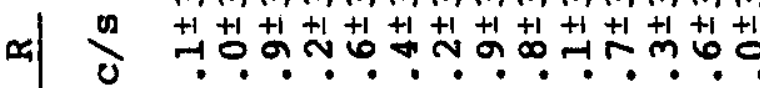

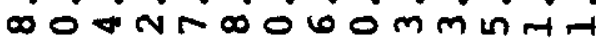

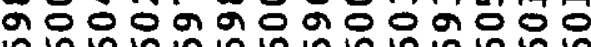

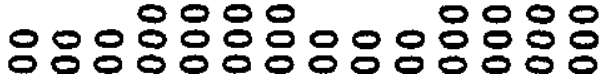
เก $x \times x x x x x x x x$

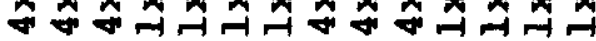
in 606 in in 6 in 66 in 666

$m m m m \neq * m m m m \forall-\forall$ $\dot{m} \dot{m} \dot{m} \dot{m} \dot{m} \dot{m} \dot{m} \dot{m} \dot{m} \dot{m} \dot{m}$ $+1+1+1+1+1+1+1+1+1+1+1+1+1+1$

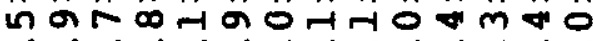
vo ina T⿻上T6. 066666666660

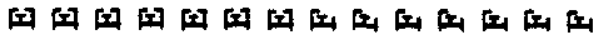

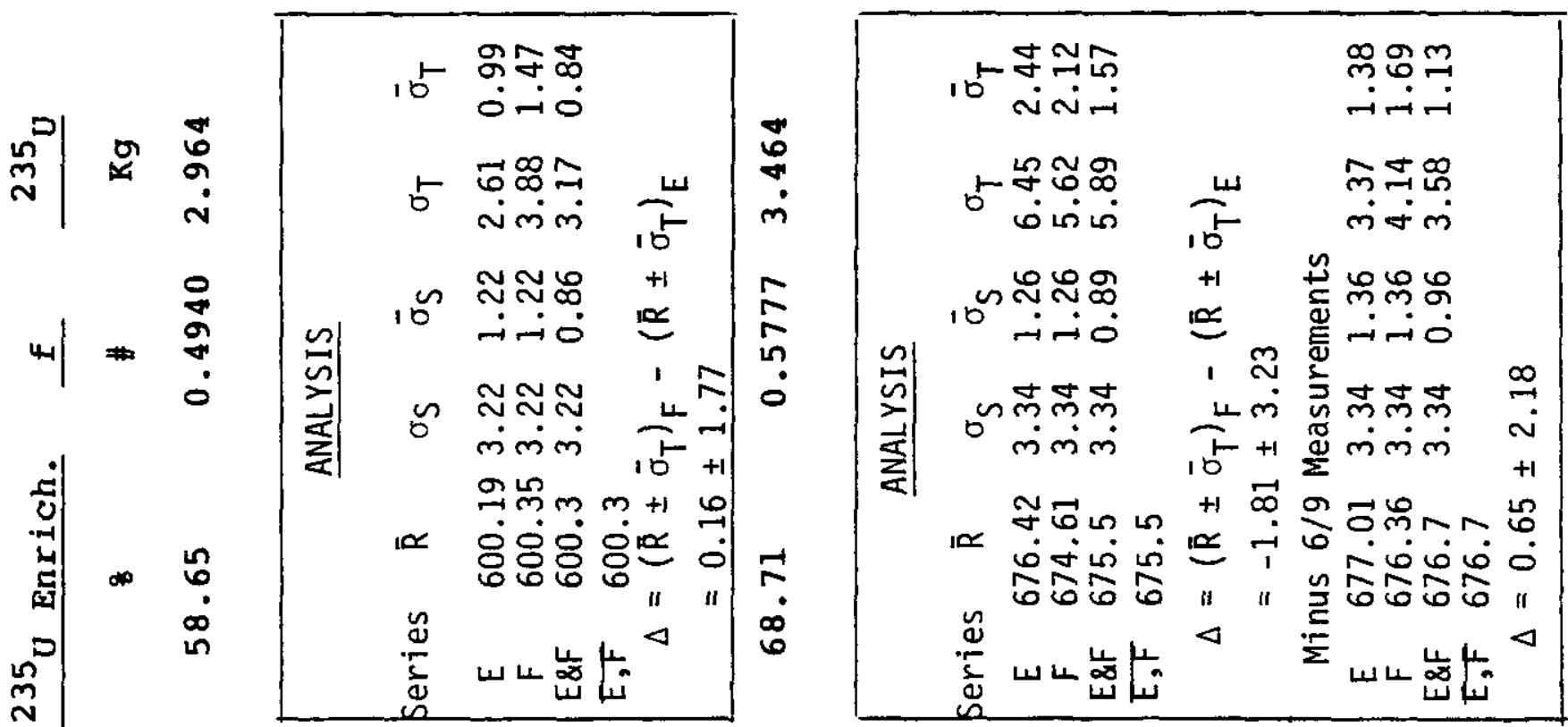


TABLE A.4 (CONT'D)

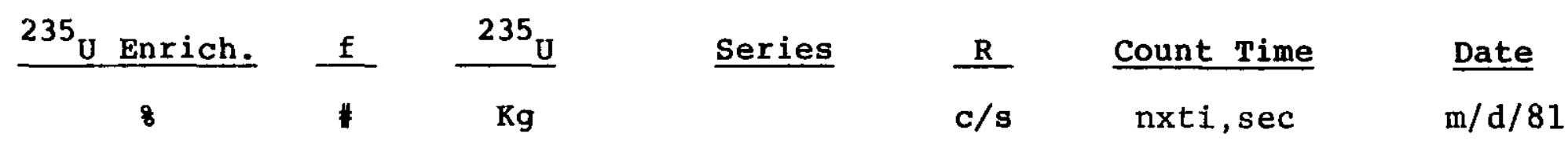

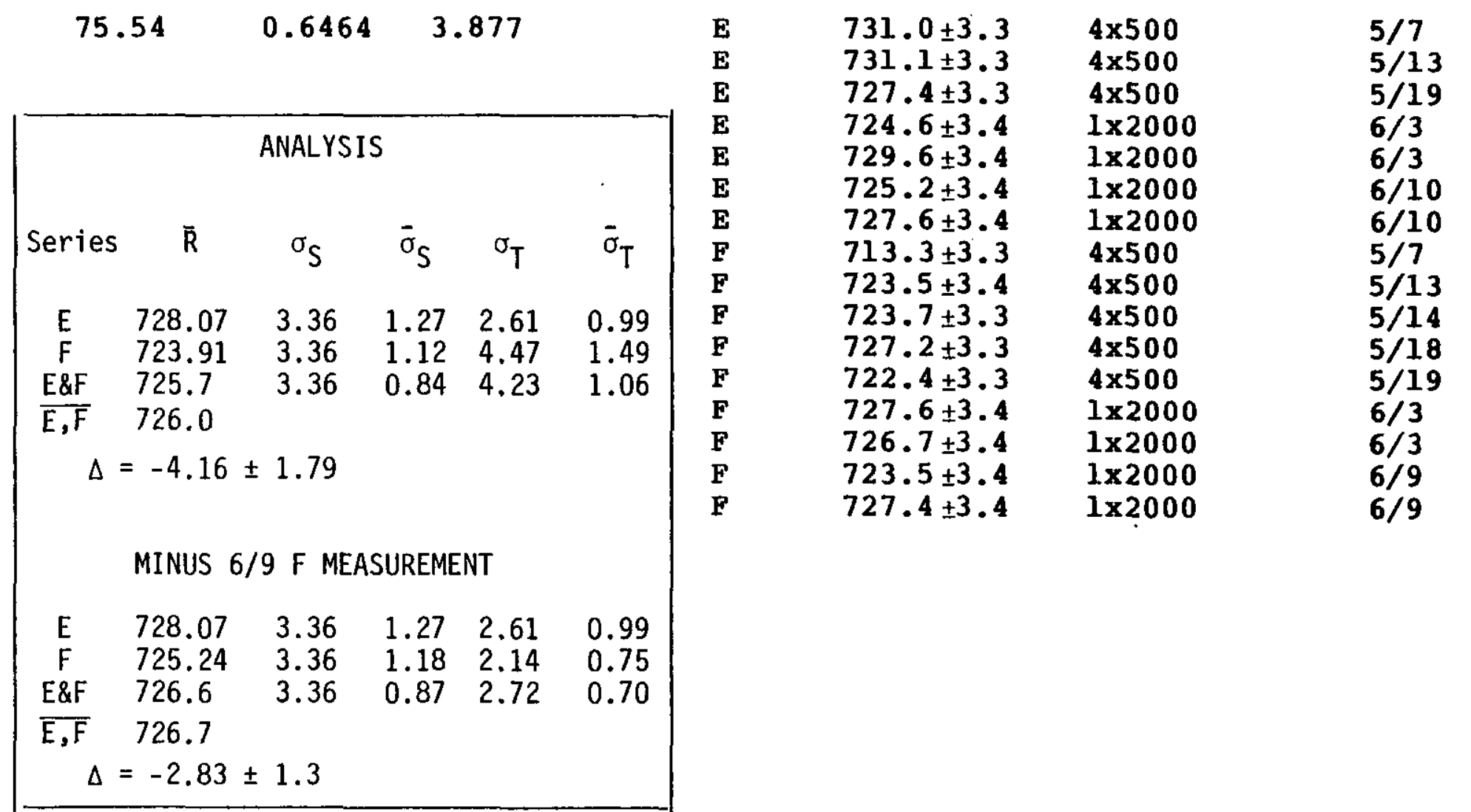




\section{TABLE A.5 NEW BRUNSWICR SAMPLES}

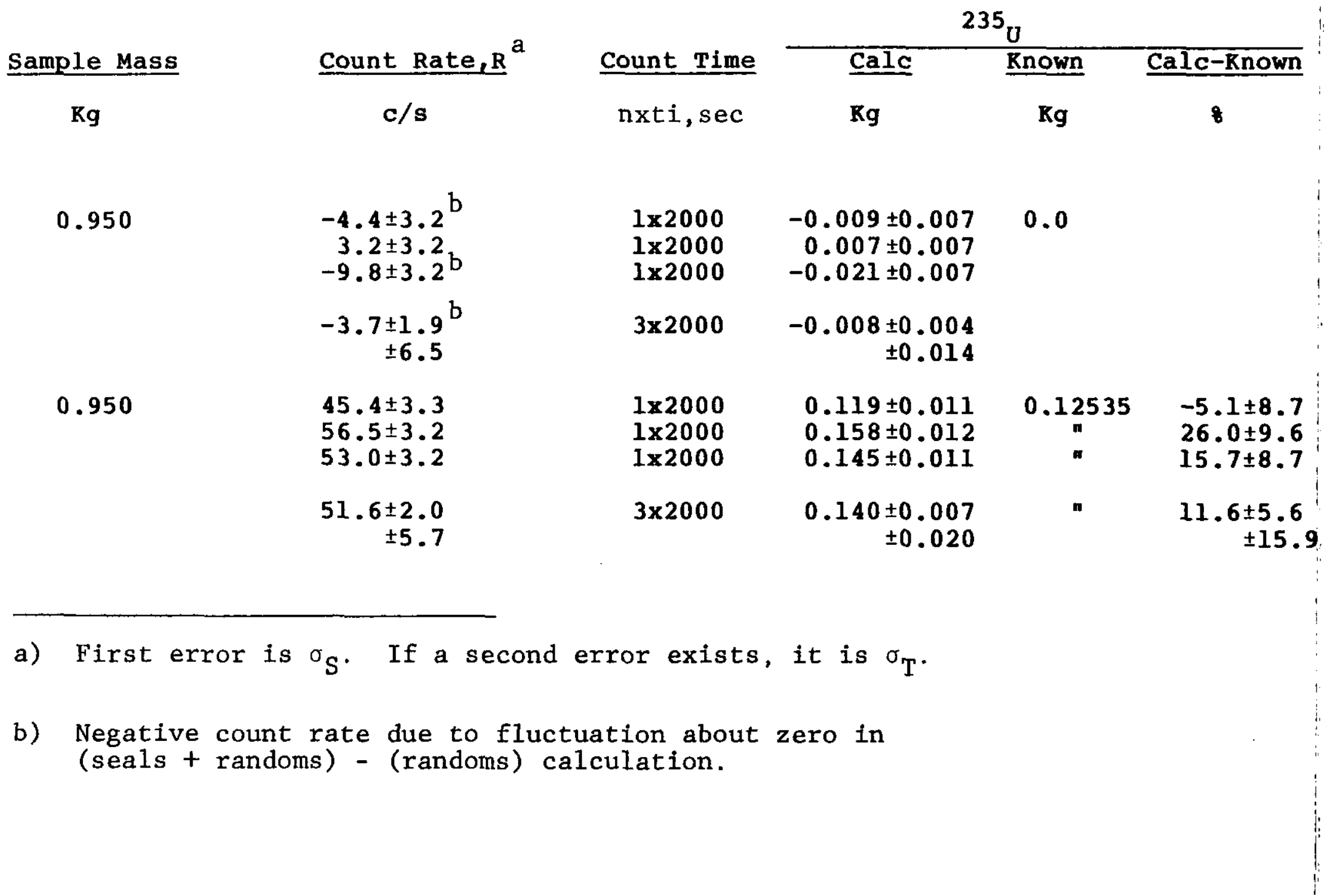




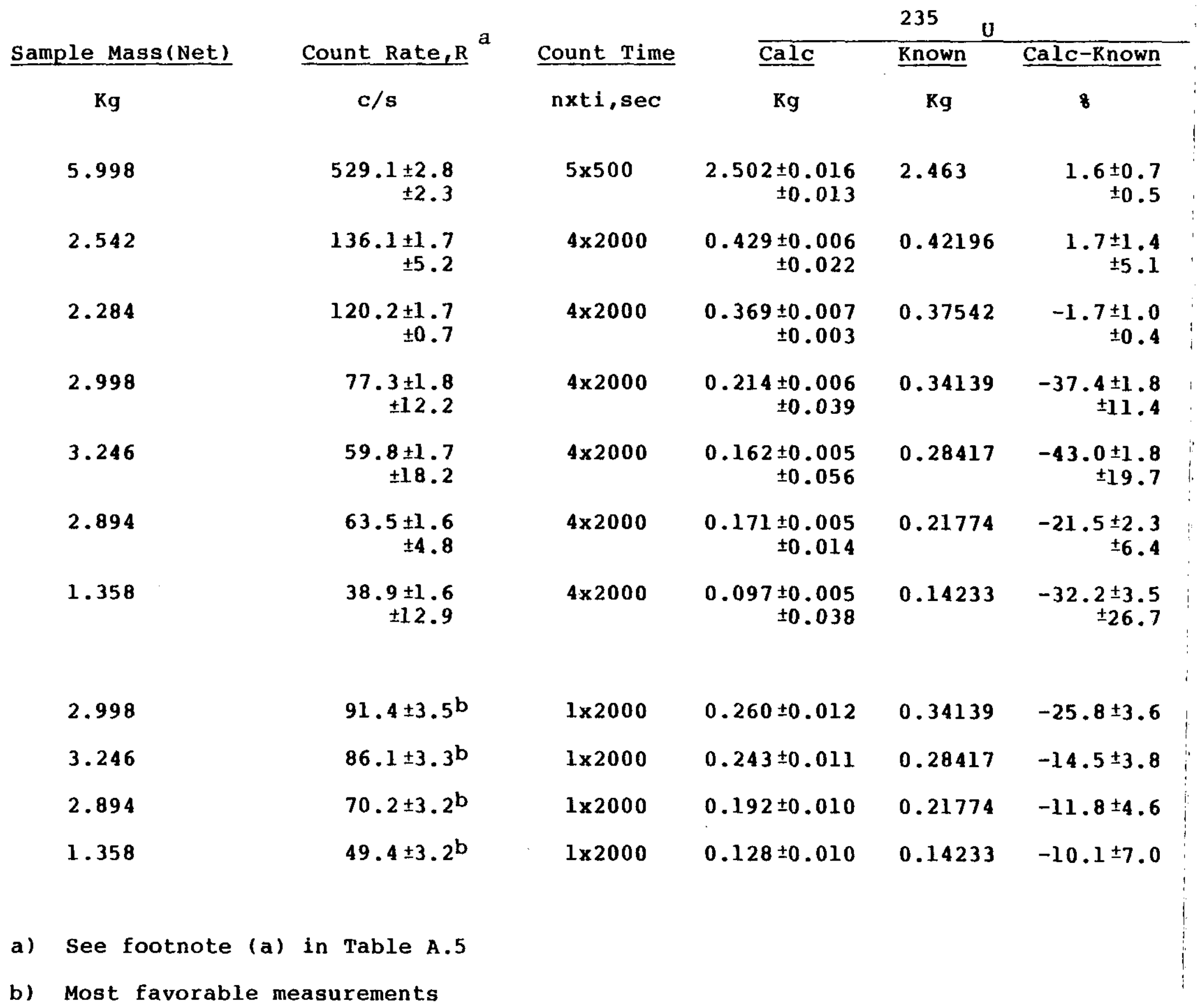

